\title{
Strategies to increase drug penetration in solid tumors
}

\author{
II-Kyu Choi ${ }^{1}$, Robert Strauss ${ }^{2}$, Maximilian Richter ${ }^{3}$, Chae-Ok Yun ${ }^{1 *}$ and André Lieber ${ }^{3}$ * \\ 1 Department of Bioengineering, College of Engineering, Hanyang University, Seoul, South Korea \\ ${ }^{2}$ Genome Integrity Unit, Danish Cancer Society Research Center, Copenhagen, Denmark \\ ${ }^{3}$ Department of Medicine, University of Washington, Seattle, WA, USA
}

Edited by:

Fabrizio Marcucci, Istituto Superiore di Sanità, Italy

Reviewed by:

Fabrizio Marcucci, Istituto Superiore di Sanità, Italy

Julie Gavard, University Paris

Descartes, France

\section{*Correspondence:}

Chae-Ok Yun, Department of Bioengineering, College of Engineering, Hanyang University, 17 Haengdang-dong, Seongdong-gu, Seoul 133-791, South Korea

e-mail: chaeok@hanyang.ac.kr; André Lieber, Department of Medicine, Division of Medical Genetics, University of Washington, Box 357720, Seattle, WA 98195, USA e-mail: lieber00@u.washington.edu
Despite significant improvement in modalities for treatment of cancer that led to a longer survival period, the death rate of patients with solid tumors has not changed during the last decades. Emerging studies have identified several physical barriers that limit the therapeutic efficacy of cancer therapeutic agents such as monoclonal antibodies, chemotherapeutic agents, anti-tumor immune cells, and gene therapeutics. Most solid tumors are of epithelial origin and, although malignant cells are de-differentiated, they maintain intercellular junctions, a key feature of epithelial cells, both in the primary tumor as well as in metastatic lesions. Furthermore, nests of malignant epithelial tumor cells are shielded by layers of extracellular matrix (ECM) proteins (e.g., collagen, elastin, fibronectin, laminin) whereby tumor vasculature rarely penetrates into the tumor nests. In this chapter, we will review potential strategies to modulate the ECM and epithelial junctions to enhance the intratumoral diffusion and/or to remove physical masking of target receptors on malignant cells. We will focus on peptides that bind to the junction protein desmoglein 2 and trigger intracellular signaling, resulting in the transient opening of intercellular junctions. Intravenous injection of these junction openers increased the efficacy and safety of therapies with monoclonal antibodies, chemotherapeutics, and T cells in mouse tumor models and was safe in non-human primates. Furthermore, we will summarize approaches to transiently degrade ECM proteins or downregulate their expression. Among these approaches is the intratumoral expression of relaxin or decorin after adenovirus- or stem cell-mediated gene transfer. We will provide examples that relaxin-based approaches increase the anti-tumor efficacy of oncolytic viruses, monoclonal antibodies, and T cells.

Keywords: epithelial junctions, tumor stroma, extracellular matrix, relaxin, junction opener, tumor-associated macrophages

\section{TUMOR MICROENVIRONMENT TUMOR STROMA}

Tumors are heterogeneous cellular entities in which progression depends on the crosstalk between the genetically abnormal cells (the epithelial parenchyma of carcinomas) and the tumor stroma (the supportive framework of a tumor tissue). This tumor stroma is basically composed of the non-malignant cells (stromal cells) of the tumor such as cancer-associated fibroblasts (CAFs), immune cells [tumor-associated macrophages (TAMs) and tumor-associated neutrophils (TANs)], and mesenchymal stem cells as well as the extracellular matrix (ECM) consisting of fibrous structural proteins (collagen and elastin), fibrous adhesive proteins (fibronectin and laminin), and proteoglycans (1-3) (Figure 1A). In most solid tumors derived from epithelial tissues, nests of malignant tumor cells are linked through junction proteins such as E-cadherin, claudins, and desmoglein 2 (DSG2). Tumor nests are surrounded by tumor stroma (Figures 1B,C). The stroma is indispensable for normal tissue development and homeostasis, since it has a vital role in regulating behavior of cells residing in the local milieu (4-7). Likewise, various components of the tumor stroma create a niche favoring seeding of metastatic tumor cells. More importantly, tumor stroma mediates the resistance to cancer therapeutic agents (8-10). Tumor stroma contributes in at least two critical ways to drug resistance: (i) by creating a physical barrier formed by stroma proteins that prevents intratumoral drug penetration and direct contact between drugs/tumor-infiltrating immune effector cells and their target receptors on malignant cells and (ii) by production of cytokines and chemokines that trigger the synthesis of stroma proteins, block activation of immune cells, or attract/activate immuno-suppressive cells such as regulatory $\mathrm{T}$ cells $\left(\mathrm{T}_{\text {regs }}\right)$.

It is well established that stroma that is associated with normal tissue development and homeostasis is strikingly distinct from that associated with carcinomas (1). Specifically, the composition of tumor-derived ECM is different from normal ECM (11). Excess ECM production or reduced ECM turnover are noticeable in the majority of tumors $(12,13)$. Various collagens (e.g., collagen type I, II, III, V, and IX), fibronectin, tenasin C, and proteoglycans exhibit increased accumulation and generate a dense network in tumor tissues (14-17). Excessive deposition of ECM components decreases the distance between neighboring ECM components and diminishes the pore size of the tumor matrix. This adds diffusional impediment to macromolecules (IgG, IgM, and dextran 2,000,000 MW) in tumors (18). A strong inverse 


\section{A}

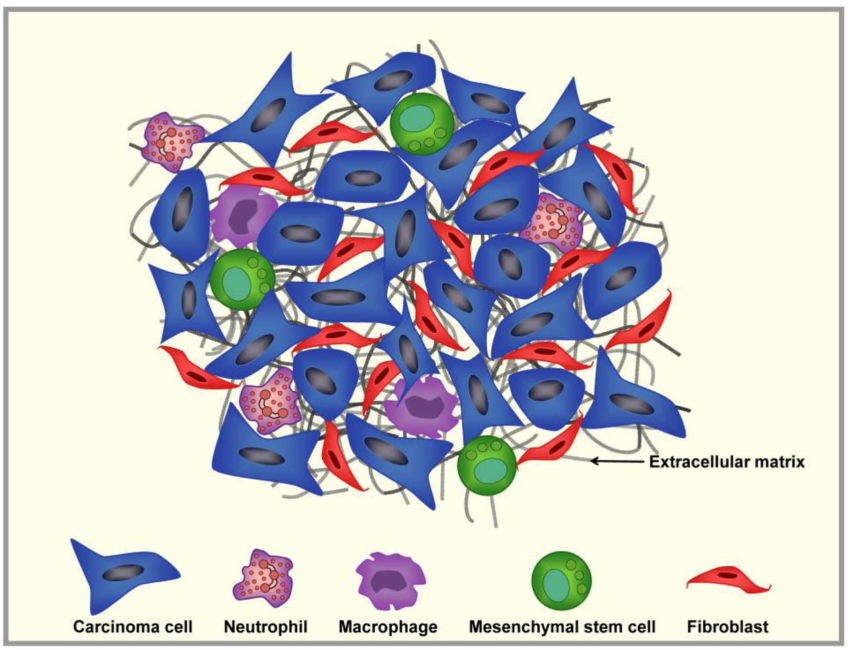

B

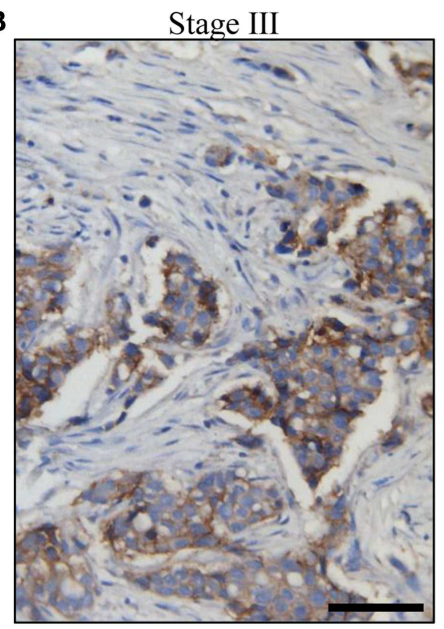

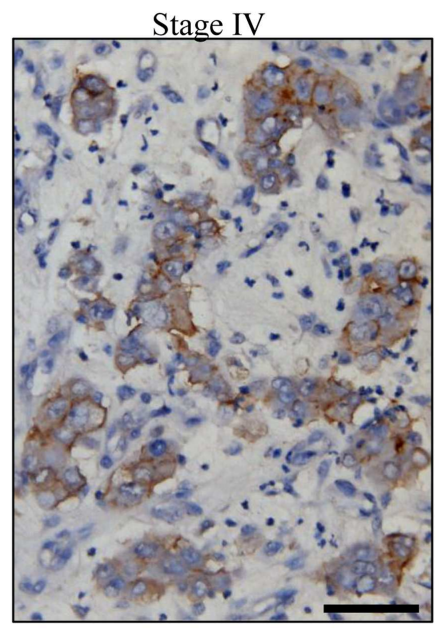

DSG 2
C

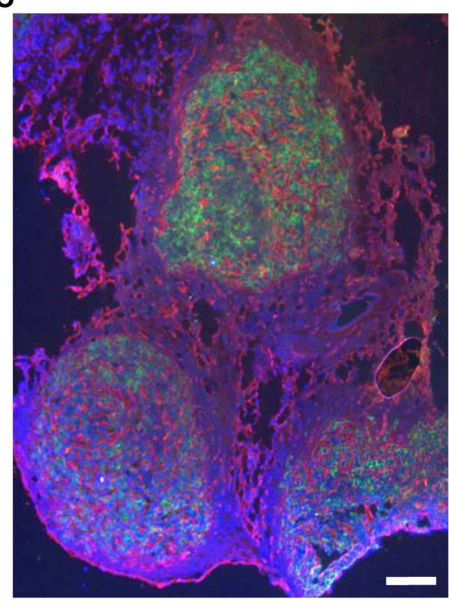

Her2/neu Laminin
FIGURE 1 |Tumor stroma. (A) Schematic representation of tumor stroma components. The tumor stroma is composed of stromal cells (fibroblasts, macrophages, neutrophils, and mesenchymal stem cells) as well as extracellular matrix. (B) Sections from breast cancer patient biopsies (stage III and IV). DSG2 staining appears in brown.
Malignant cells are DSG2-positive and form nests that are surrounded by tumor stroma containing DSG2-negative stroma cells such as fibroblasts. (C) Immunofluorescence analysis for Her2/neu (green) and the stroma protein laminin (red) on a breast cancer section. The scale bar is $20 \mu \mathrm{m}$. correlation between tumor ECM content and tumor penetration of cancer drugs has been demonstrated for therapeutic agents such as anti-tumor immune cells, therapeutic viruses, chemotherapeutic agents, monoclonal antibodies, immunotoxins, interferons, and complement (18-24). Due to increased ECM deposition, tumor tissue commonly exhibits increased stiffness compared to normal tissue. For breast cancer, tumor tissue was found to be 10 times stiffer than normal breast tissue $(26,27)$. The elevated ECM stiffness progressively increases interstitial fluid pressure (IFP) which thereafter interferes with effective spread of anti-cancer therapeutics within the solid tumor (28-30). In summary, the deregulation and disorganization of the tumor stroma alter the composition, structure, and stiffness of the ECM, leading to limited penetration and dissemination of therapeutic agents within solid tumors.
Killing the genetically stable tumor stroma cells has definitive advantages over targeting the malignant cells, i.e., cells that are genetically unstable and heterogeneous and represent a moving target for therapies.

\section{TUMOR STROMAL CELLS}

The major contributors of abnormal ECM in solid tumors are stromal cells such as cancer-associated fibroblasts (CAFs), TAMs, and TANs $(3,13,31)$. These stromal cells display sustained synthesis and secretion of connective tissue components, growth factors, and cytokines, which promote the ability of malignant cells to proliferate, invade, and metastasize $(32,33)$. Thus targeting the tumor stromal cells is considered a promising approach to the treatment of cancer. 


\section{Cancer-associated fibroblasts}

Cancer-associated fibroblasts are the predominant cell type in the tumor-associated stroma. Their numbers are elevated in tumor stroma compared to stroma found in healthy tissue $(34,35)$. In many carcinomas, the fraction of CAFs is even greater than the fraction of malignant cells (32). In the tumor microenvironment, tumor and stromal cells upregulate various profibrotic growth factors such as transforming growth factor- $\beta$ (TGF- $\beta$ ), plateletderived growth factor (PDGF), and basic fibroblast growth factor (bFGF), all of which are main mediators for the transdifferentiation of stromal fibroblasts into CAFs $(36,37)$. CAFs are phenotypically and functionally distinct from normal stromal fibroblasts (38). CAFs are large spindle-shaped mesenchymal cells that share morphological characteristics of both smooth-muscle cells and fibroblasts (39). Metabolically, CAFs are perpetually activated, proliferate faster, and accumulate greater amounts of ECM constituents than fibroblasts in normal tissues $(2,32,40)$. In addition to creating tumor-derived ECM, CAFs have an impact on cancer cell proliferation, invasion, and metastasis through secretion of different growth factors [epidermal growth factor (EGF), FGF, hepatocyte growth factor (HGF), and insulin-like growth factor1 (IGF-1) $(2,3,31,34,41-44)]$. CAFs are also involved in the activation of angiogenic programs as well as the recruitment of inflammatory cells (45). Local expression of vascular endothelial growth factor (VEGF) or monocyte chemoattractant protein-1 (MCP-1) by CAFs stimulates angiogenesis and the recruitment of pro-tumor myeloid cells.

\section{TAMs and TANs}

As another major component in the tumor stroma, TAMs have emerged as a significant player in the stromal compartment of virtually all types of carcinoma (46). While type M1 macrophages are antigen-presenting cells that incite $\mathrm{T}$ cells to mount immune responses, TAMs are M2-type macrophages and tumor promoting. Tumor cells, among other cytokines, produce MCP-1 and colony stimulating factor-1 (CSF-1) which participates in mobilization of TAM-progenitors from the bone marrow and homing to tumor stroma. Homing of TAMs to tumors is also supported by the specific architecture of tumor blood vessels which promote efficient trafficking of blood cells. There is convincing evidence that the extent of MCP-1 expression in human cancers correlated with both TAM infiltration and tumor malignancy (47-53). TAMs contribute to tumor-associated alteration in the ECM by releasing profibrotic growth factors, which then act in an autocrine and/or paracrine manner to differentiate normal stromal fibroblasts into CAFs $(33,37,46)$. TAMs also produce growth factors (EGF, HGF, bFGF, and VEGF), cytokines [IL-1, IL-8, and tumor necrosis factor- $\alpha$ (TNF $\alpha)$ ], and enzymes [MMP-2, MMP7, MMP-9, MMP-12, and cyclooxygenase-2 (COX-2)] $(46,54)$. Additionally, TAMs can suppress anti-tumor immune responses. For example, TAMs secret a distinctive set of cytokines (IL-10 and TGF- $\beta$ ) as well as chemokines [chemokine (C-C motif) ligand (CCL) 17, CCL22, and CCL24] favoring recruitment of $\mathrm{T}_{\text {regs }}$ and generation of an immune suppressive microenvironment (5557). As outlined in Section "Epithelial-to-Mesenchymal Transition and Mesenchymal-to-Epithelial Transition in Cancer," TAMs also promote epithelial-to-mesenchymal transition (EMT) via TGF- $\beta$
(58) and regulate cancer stem cell (CSC) activities (59) in solid tumors.

Tumor-associated neutrophils comprise another prominent portion of the immune cell infiltrates observed in a wide variety of murine models and human cancers (60-63). Similar to TAMs, products secreted from neutrophils, including reactive oxygen species, cytokine (IL-8), growth factors (VEGF and HGF), and proteinases [arginase (ARG 1), MMP-2, MMP-8, MMP-9, and MMP-13], have defined and specific roles in both regulating tumor cell proliferation, angiogenesis, and metastasis and suppressing the anti-tumor immune response (64).

\section{TUMOR VASCULARIZATION}

\section{Transendothelial transport}

Once systemically administered drugs reach the tumor sites, they have to exit the tumor vasculature and translocate through the interstitial space in order to reach their target cells. The endothelial cell layer, lining the blood vessels, is thought to present a barrier to macromolecular drugs (20). Transendothelial transport of macromolecular drugs involves a phenomenon known as the enhanced permeability and retention (EPR) effect in solid tumors. The EPR effect is observed for intravenously administered macromolecular anti-cancer drugs that escape renal clearance, due to their large molecular size $(10-500 \mathrm{~nm})$. They are mostly unable to pass the tight endothelial junctions of normal blood vessels, but can extravasate and then become trapped in the tumor vicinity (65). Unlike normal tissues that feature an organized vascular network, the blood vessel system in solid tumors is rather chaotic. The endothelial cell layers are poorly aligned (66) and elevated levels of vascular permeability factors generate "leaky" capillaries (65). It is therefore thought that transendothelial transport is not a critical limiting obstacle for large sized drugs.

\section{Intratumoral pressure}

Rapid tumor cell proliferation and weakly developed lymphatics cause high IFP $(67,68)$ and blood vessel remodeling by intussusception (69) or compression (70). Additionally, the increased hydraulic conductivity of "leaky" capillaries can further increase the IFP in tumors (71). Together, this leads to an imbalance in blood flow and nutrient supply within the tumor microenvironment. The uniformly high IFP in the center of solid tumors drops toward the periphery (72), which could negatively affect drug extravasations in the high-pressure regions. Cells that are distant to blood vessels (100-200 $\mu \mathrm{m})$ and located in high-pressure regions subsequently constitute large areas of hypoxic, necrotic, or seminecrotic tissue. This exacerbates the tendency of tumor cells to overproduce and release lactic acids within these regions, which results in acidosis (73). Moreover, the vascular surface area per unit tissue weight is decreasing with tumor growth, which further limits transvascular exchange for large tumors when compared to small tumors $(74,75)$. In contrast, cells situated in the invasive front benefit from the enhanced vascular permeability that supplies adequate amounts of macromolecules for rapid tumor growth (76). Furthermore, the blood flow rates in non-necrotic regions can be substantially higher than in the surrounding normal tissue (77). It is therefore expected that the uptake of drugs in solid tumors is heterogeneous and the general distribution might 
decrease with increasing tumor weight. It is thought that induction of massive cell death by chemo- and radio-therapy can lower the IFP in tumors (78). The application of chemotherapy to lower the IFP is also used in approaches to "normalize" the tumor vasculature. Anti-angiogenic drugs are thought to compensate for the pro-angiogenic factors that are extensively produced in the tumor in order to eliminate "leaky" blood vessels. Ideally, this would lead to a more organized blood vessel system that features more functional and more uniformly perfused capillaries within solid tumors. On the other hand, this would also inhibit the extravasation of large drugs.

\section{Hypoxia}

Two major consequences of abnormal microcirculation in solid tumors are hypoxia and low extracellular $\mathrm{pH}$. Hypoxia or oxygen deprivation is a key factor in tumor progression and resistance to therapy. The most important regulatory factor of the hypoxiasignaling pathway activity in cells is hypoxia-inducible transcription factor 1 (HIF-1 $\alpha$ ). Under hypoxic condition, tumors produce a number of chemokines that attract and differentiate CAFs, TAMs, and TANs. Approaches that reduced intratumoral hypoxia therefore block pro-tumoral functions of these cells, including the production of stroma proteins. It is therefore thought that hypoxia targeting strategies improve the intratumoral penetration of drugs (79).

\section{EPITHELIAL PHENOTYPE OF SOLID TUMORS EPITHELIAL JUNCTIONS}

About $90 \%$ of solid tumors are of epithelial origin, often featuring a stratified epithelium characterized by multilayered cells with three-dimensional intercellular junctions. This is in contrast to monolayered epithelial cells lining epithelial tracts (e.g., airway, gastrointestinal, and urinary tracts), epithelial ducts (e.g., bile and pancreatic ducts), or cavities (e.g., brain ventricles), which possess an apical-basal polarization of their cell membranes and cytoskeleton. The epithelial phenotype is generally defined by tight and adherence junctions that seal the paracellular space between adjacent cells and thereby providing a barrier that restricts passing of ions and macromolecules (Figure 2A) (80).

\section{Tight junctions (zonula occludens)}

Tight junctions play a key role in the formation of epithelial sheets. Strictly linked to tight junctions is a barrier function within a sheet of cells that restricts ions and small molecules to pass through the paracellular space between two adjacent epithelial cells (80). Additionally, tight junctions function as a "fence" that separates the apical and basal membrane compartments in an individual cell (81). Importantly, the tight junction strands on one cell are associated laterally to tight junction strands of opposing membranes on neighboring cells (82). The permselective barrier function is based on occludins and claudins, two types of transmembrane proteins that have been identified among more than 40 proteins within tight junctions $(81,83)$. Other tight junction transmembrane proteins comprise the singlespan junctional adhesion molecules (JAMs) or coxsackie and adenovirus receptor (CAR) (83-86) and the lately identified tetraspan tricellulin, which is enriched in areas where three cells meet (86).

\section{Adherens junctions (zonula adherens)}

The major transmembrane proteins of adherens junctions are classical cadherins, such as epithelial cadherin (E-cadherin). Members of this protein superfamily promote homophilic intercellular adhesion in a $\mathrm{Ca}^{2+}$-dependent manner. Their cytoplasmic domain binds cytosolic catenins that link the cadherin/catenin complex to the actin cytoskeleton. The formation of adherens junctions consequently leads to the assembly of tight junctions, but E-cadherin is dispensable for tight junction maintenance (87). A central role in maintenance and initiation of an epithelial phenotype is attributed to E-cadherin, the core protein of adherens junctions. In addition to its homophilic intercellular adhesive features, the extracellular E-cadherin domain functions as a direct repressor of receptor tyrosine kinase (RTK) signaling via blockage of FGF or EGF ligand binding stimulation $(88,89)$. The cytoplasmic part of E-cadherin connects to the actin cytoskeleton and also influences a number of signaling pathways via direct binding to p120- and $\beta$-catenin. When adjunct to E-cadherin at the membrane, $\beta$-catenin inhibits cell growth (90), whereas its translocation to the nucleus activates canonical Wnt signaling (91). Similarly, p120-catenin stabilizes Ecadherin at the membrane, while blocking NF- $\kappa$ B and Ras-MAPK signaling $(92,93)$.

\section{Desmosomal junctions/desmosomes (macula adherens)}

Desmosomes are molecular complexes of cell adhesion proteins and linking proteins that attach the cell surface adhesion proteins to intracellular keratin cytoskeletal filaments. The cell adhesion proteins of the desmosome, desmoglein, and desmocollin, are members of the cadherin family of cell adhesion molecules. They are transmembrane proteins that bridge the space between adjacent epithelial cells by way of homophilic binding of their extracellular domains to other desmosomal cadherins on the adjacent cell. Both have five extracellular domains, and have calcium-binding motifs. One of these junction proteins, DSG2, is upregulated in malignant cells $(94,95)$. DSG2 contains four extracellular cadherin domains (ECDs; ECD1-ECD4), which link neighboring cells to each other through homodimers. ECDs are linked via an extracellular anchor and membrane-spanning domain to the intracellular anchor and intracellular cadherin-typical sequence (ICS) motifs. The role of the conserved ICS is not known, although consensus sites for protein kinase $\mathrm{C}$ phosphorylation and a caspase-3 cleavage site have been identified and could contribute to signaling (96). Desmosomes probably do not directly regulate paracellular permeability, but they seem to do this indirectly by altering the structure and the stability of tight junctions (97).

\section{BLOCK OF INTRATUMORAL DIFFUSION OF MACROMOLECULES}

One of the key features of epithelial tumors is the presence of intercellular junctions, which link cells to one another, and act as barriers to the penetration of molecules with a molecular weight of $>400 \mathrm{Da}$ (98-100). Most of commonly used chemotherapy drugs are either nanoparticle-based or encapsulated into liposomes with diameter greater than $100 \mathrm{~nm}$. For example, nanoparticle albumin bound paclitaxel/nab-paclitaxel/Abraxane ${ }^{\mathrm{TM}}$ has an effective diameter of $130 \mathrm{~nm}$ and liposomal doxorubicin/Doxil ${ }^{\mathrm{TM}}$ has a size of $90 \mathrm{~nm}$. Even non-encapsulated chemotherapy drugs have a molecular weight of greater $400 \mathrm{Da}$ (for example: paclitaxel/Taxol ${ }^{\mathrm{TM}}$ : MW 
A

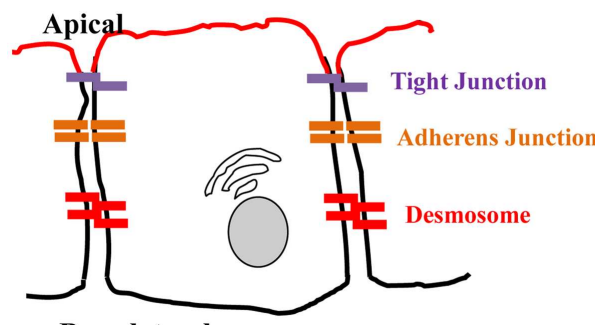

Baso-lateral
B

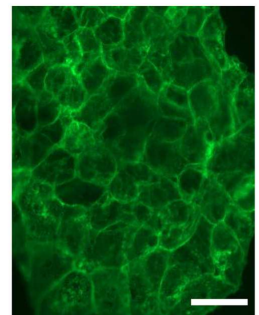

Her2/neu

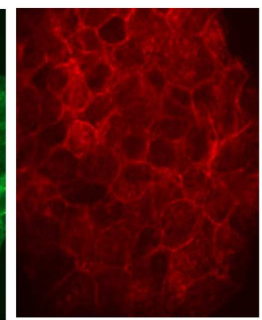

Claudin 7

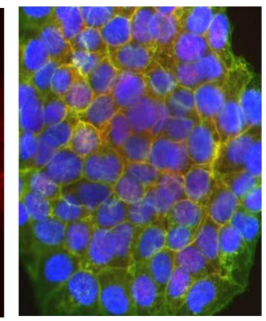

Her2/neu Claudin 7
FIGURE 2 | Architecture of epithelial cells. (A) Adjacent epithelial cells maintain several intercellular junctions and an apical-basal polarity. Tight junctions seal the paracellular space close to the apical side. Initial cell contact is initiated by cadherins in the adherens junction complex that is situated underneath tight junctions. Adherens junction complexes encircle cells as an adherens belt, which connects to the F-actin cytoskeleton. Desmosomes are spot-like adhesions randomly arranged on lateral sides of plasma membranes. A key desmosomal junction protein is desmoglein 2 (DSG2). (B) Target receptors for cancer therapy are often trapped in epithelial junctions. Shown are breast cancer cells stained for Her2/neu (the target receptor for trastuzumab/Herceptin ${ }^{\mathrm{TM}}$ ) and the junction protein claudin 7. The merged image shows colocalization of both proteins in junctions between cells.
856.9 Da or irinotecan/Camptosar ${ }^{\mathrm{TM}}$ : MW 586.7 Da). Several studies have shown that upregulation of epithelial junction proteins correlated with increased resistance to therapy, including therapy with the two major classes of cancer drugs - monoclonal antibodies and chemotherapeutics (101-103). It is thought that the epithelial phenotype of cancer cells and their ability to form physical barriers protect the tumor cells from attacks by the host-immune system or from elimination by cancer therapeutics (104).

\section{INACCESSIBILITY OF THERAPY TARGET RECEPTORS}

Receptors for therapeutic antibodies are often localized at the basolateral membrane of epithelial cells. This includes Her2/neu (105, $106)$ and EGFR $(107,108)$. In our studies on epithelial tumors we found that target receptors are trapped in intercellular junctions (109). For example, Her2/neu, the receptor for the widely used monoclonal antibody Herceptin (trastuzumab) co-stained with the tight junction proteins claudin 7 (Figure 2B).

\section{EPITHELIAL-TO-MESENCHYMAL TRANSITION AND MESENCHYMAL-TO-EPITHELIAL TRANSITION IN CANCER}

Epithelial-to-mesenchymal transition and mesenchymal-toepithelial transition (MET) are important mechanisms that drive tumor progression and therapy resistance, and indirectly affect intratumoral drug penetration. EMT and MET have been accredited important roles in embryogenic development, tissue regeneration, cancer progression, and recently also the induction and maintenance of stem cell properties (110). Importantly, the phenotypic switches between epithelial and mesenchymal phenotypes are not irreversible, as they occur several times during formation of the complex three-dimensional structure of internal organs. In contrast to epithelial cells, mesenchymal cells exhibit an irregular shape, which is based on unpolarized cytoskeletons and membranes. Further mesenchymal traits include the deposition of ECM components, increased motility, invasiveness, as well as elevated resistance to apoptosis and anoikis (110). EMT engages a series of events involving inter- and intra-cellular changes in affected cells. Importantly, not all of which have to occur during the transdifferentiation process. Often cells remain in stages referred to as an "incomplete" EMT, suggesting a spectrum of intermediate stages rather than a strict lineage switch (104). Examples of such epithelial/mesenchymal (E/M) hybrid cells have been reported for multiple tissues including the ovarian surface epithelium (111), ovarian cancer (25), cells within the invasive front of colon (112) and breast cancer (113), as well as in normal epidermal tissue during wound healing (114).

\section{EMT and induction of tumor ECM proteins}

During progression toward metastatic disease carcinoma cells engage EMT. The EMT program can be activated by a multitude of factors secreted by tumor stroma cells, which triggers a complex signaling network including TGF- $\beta$, Wnt, HGF, EGF, and PDGF pathways (115). The morphological changes that occur during EMT are a consequence of diverse molecular mechanisms that contribute to the acquisition of mesenchymal features. A central event during EMT is the functional loss of E-cadherin. Subsequent breakdown of intercellular epithelial junctions plays a major role in cancer progression, where E-cadherin therefore acts as a repressor of invasion (116). Accordingly, the reduced expression of this major regulator of the epithelial phenotype is associated with poor prognosis in several cancers (117). The loss of E-cadherin and several other epithelial genes including multiple members of the claudin family as well as occludin is mainly regulated via transcriptional repression by EMT inducers that include transcription factors Snail, ZEB, Twist, FOXC2, and E47 (118-126). Notably, these EMT inducers also act as positive regulators of gene expression for several mesenchymal genes $(127,128)$. A consequent event in EMT is the change from E-cadherin to N-cadherin (129). The importance of this cadherin switch is highlighted by the fact that homophilic intercellular junctions formed by $\mathrm{N}$-cadherin are less resistant to rupture under physiological stress conditions, when compared with E-cadherin (130). Additionally, a shift from several keratins $(-8,-9$, and -18$)$ to vimentin occurs, resulting in a more flexible cytoskeleton $(131,132)$. Concomitantly with the acquisition of such mesenchymal features, the expression of several ECM proteins is induced. Fibronectin, collagen precursors, laminin, and vitronectin are all reported to be elevated in mesenchymal cells (133). These and other proteins, including Src kinase, integrinlinked kinase, integrin $\beta-5$, and MMPs, are upregulated during 
EMT, have an impact on cytoskeletal remodeling, and promote cell motility (104).

\section{MET and cancer stem cells}

Successful EMT induction ultimately enables cancer cells to leave the primary tumor, enter the bloodstream, and attach to distant organ sites in order to build metastases. The endpoint of this process however, involves the reversed process (MET), where cells that underwent EMT regain epithelial properties and form tumors that histopathologically resemble the primary cancer $(110,134)$. Although the underlying mechanisms are currently unknown, it is likely that MET events are initiated due to the lack of EMTinducing signals at attachment sites of metastatic tumor cells. In support, numerous examples of advanced carcinomas exist, showing that mesenchymal cells can regain characteristics of epithelial cells or undergo MET (104). It is now generally accepted that the reverting to an epithelial phenotype through MET represents a protective mechanism against host-immune attacks and creates resistance to anti-cancer drugs. The transdifferentiation into an epithelial phenotype and the formation of tight junctions between malignant cells that prevent penetration of host antitumor immune cells, host anti-tumor antibodies, and therapeutics represents one of the most basic cancer resistance mechanisms.

Importantly, changes between EMT and MET occur gradually, which leads to a wide range of intermediate cell stages that consequently possess an E/M hybrid phenotype. The E/M hybrid phenotype is especially prominent in the invasive front of several carcinomas where it has also initially been linked to cells with a stem cell-like phenotype $(112,113)$. We have recently shown in cancer cells derived from ovarian cancer biopsies that CSCs generate mesenchymal cells via EMT in vitro and undergo MET to form tumors containing epithelial cells when injected into immunodeficient mice (135). A marker combination widely used to identify CSCs in multiple cancers including prostate, pancreatic, and colon is EpCAM and CD44 (136, 137). Interestingly, the expression of these proteins can be accredited to epithelial and mesenchymal cells, respectively, suggesting a more general pattern of an E/M hybrid phenotype for tumor-initiating cells (TICs) (25). Very recently, work by Yu et al. demonstrated that cells, which leave the primary tumor, possess an epithelial or E/M hybrid phenotype. In the bloodstream these circulating tumor cells are bound by platelets, which trigger EMT via TGF- $\beta$ signaling (138). However, cells undergoing EMT that leave the primary tumor experience a proliferation arrest, which is mediated by EMT inducers, like Twist1. In order to reenter a proliferative stage that allows for colonization and macrometastasis, the downregulation of Twist1 and concomitant MET is critically needed, while ongoing EMT signaling leads to dormancy and micrometastases at sites of reattachment (139). Additionally, it was recently reported that two distinct types of EMT exist in carcinomas, depending on the presence or absence of EMT inducer paired-related homeobox transcription factor 1 (Prrx1). When Prrx1 is expressed in cells undergoing Twist1-induced EMT, a CSC pattern is suppressed and cells fail to colonize. After Prrx1 is downregulated and other EMT inducers, such as Twist1 or ZEB1 have vanished, MET occurs and metastatic growth can be initiated (140). Notably, MET has also been reported in non-epithelial cancers, e.g., sarcoma $(141,142)$.

\section{STRATEGIES TO DEGRADE TUMOR ECM PROTEINS OR DOWNREGULATE THEIR EXPRESSION}

Tumor-derived ECM plays an important role in inhibiting penetration and dispersion of cancer therapeutic agents within tumor masses and has been implicated in resistance to therapy of solid tumors (143). This has been shown for therapeutic modalities such as oncolytic Ads (21), antibodies $(18,19)$, immunotoxins (24), interferons (23), or complement (144). A series of approaches have been tested to partially degrade ECM proteins and improve the penetration of macromolecules and nanoparticle-based drugs. (i) The first type of approaches involves the intratumoral injection of proteases that can target ECM proteins. These proteases include trypsin, collagenase, hyaluronidase, MMPs, relaxin, and decorin. For example, intratumoral injection of collagenase has been shown to remove diffusive hindrance to the penetration of therapeutic molecules in subcutaneous human osteosarcoma and glioblastoma multiforme xenografts $(145,146)$. Similar approaches have been tested in combination with cancer virotherapy, including Ads (diameter: $\sim 100 \mathrm{~nm}$ ) and herpes simplex virus (HSV) (diameter: $\sim 190 \mathrm{~nm}$ ). These viruses represent prototypes of nano-particles and lessons learned from studies with oncolytic viruses are relevant for other large anti-cancer drugs. Direct injection of subcutaneous human glioblastoma multiforme tumor with a proteolytic enzyme (trypsin) or a protease mixture (collagenase/dispase) before intratumoral injection with reporter gene-expressing Ad vector elicited enhanced virus-mediated gene expression within the solid tumor (147). Intratumoral co-injection of collagenase with an oncolytic HSV vector in a human melanoma xenograft resulted in increased intratumoral viral spread and therapeutic benefit (148). Likewise, co-delivery of hyaluronidase and oncolytic Ads led to improved intratumoral diffusion and virus potency through degradation of hyaluronan-rich ECM in human prostate and melanoma xenograft models (149). (ii) The second approach involves the delivery of a protease-encoding gene expression cassette to tumors. Cheng et al. generated replication-incompetent Ads expressing MMP-8 that breaks down collagen type I, II, and III in subcutaneous human A549 lung cancer and BxPC3 pancreatic cancer xenograft tumors (150). In studies testing MMP-8-expressing Ads, MMP-8 expression efficiently degraded collagen in vitro. Furthermore, co-injection of MMP-8-expressing Ads in combination with wild-type Ads resulted in reduced tumor cell growth and collagen expression within areas of virus-induced necrosis compared with wild-type Ad given together with a control Ad vector. Moreover, Mok et al. showed that intratumoral expression of MMP-1 and MMP-8 in the human HSTS26T soft tissue sarcoma xenograft degraded collagen, reduced the levels of sulfated proteoglycans, and increased spread and effectiveness of an oncolytic HSV (151). While degradation of ECM with enzymes, such as collagenase and MMPs, may improve viral penetration and distribution, there is a concern that this strategy may also increase tumor spread; MMPs and collagenase play an important role in tumor invasion and metastasis, which might limit the use of these proteins in a clinical setting $(152,153)$. Therefore, further thorough and detailed studies are required to gain an improved understanding of the potential risk associated with combined replicating oncolytic virus and ECM-degrading enzyme or protein therapy. 
Our laboratories have tested approaches involving the expression of relaxin (154-157) or decorin (158). We will therefore describe these approaches in more detail.

\section{RELAXIN-BASED APPROACHES TO INCREASE DRUG PENETRATION IN SOLID TUMORS}

Relaxin is an insulin-related peptide hormone (159). During pregnancy, relaxin has an integral role in softening the uterine cervix, vagina, and interpubic ligaments in preparation for parturition (160). Relaxin is the ligand for two leucine-rich repeat-containing G protein coupled receptors (LGRs), LGR7, and LGR8, now classified as relaxin family peptide receptors 1 and 2 (RXFP1 and RXFP2), respectively (161). These receptors have been found on relaxin target tissues, particularly on endometrial stromal cells and CAFs (161). Binding of relaxin to these receptors triggers intracellular signaling resulting in downregulation of ECM protein expression and upregulation of MMPs, which degrade stroma proteins. Importantly, relaxin decreases the synthesis of collagens and increases the expression of MMPs when collagen is abnormally upregulated, but it does not significantly alter basal levels of collagen expression, in contrast to other collagen-modulatory cytokines (e.g., interferon- $\gamma)(162)$. This implies that relaxin acts predominantly on tissues with increased ECM protein expression such as fibrotic tissues and tumors. In agreement with these observations, earlier reports showed that relaxin expression mediated by an Ad vector reversed cardiac fibrosis without adversely affecting normal collagen levels in other organs in a transgenic murine model of cardiac fibrosis (163). Relaxin has been used for degradation of tumor-derived ECM components (164). In immunodeficient mice bearing human HSTS26T soft tissue sarcomas in dorsal skinfold chamber, chronic relaxin treatment via osmotic pumps elicited improved collagen down-regulation and intratumoral dispersion of macromolecules in tumor tissues, whereby the new tumor ECM, that is generated after relaxin treatment, was more porous and had a decreased diffusive resistance (145). In vitro studies with human OHS osteosarcoma multicell spheroids, recombinant relaxin increased the diffusion of the $150 \mathrm{kDa}$ FITC-dextran, in part, due to increased production of collagenase (146). Similar results were reported in in vivo tumor models after intratumoral injection of recombinant relaxin (145). In cancer virotherapy studies, relaxin was demonstrated to enhance tumor penetration and dispersion of oncolytic Ad, thereby eliciting improved cancer gene therapy (155) (Figure 3). In this study, the growth of both subcutaneous xenograft (human glioma, hepatocellular carcinoma, cervical carcinoma, and lung carcinoma) and orthotopic tumors (human hepatocellular carcinoma) treated with relaxin-expressing oncolytic Ad was markedly inhibited compared to tumors treated with control oncolytic Ad that did not express relaxin. When viral persistence and distribution was confirmed by immunohistochemical studies, more Ad particles were observed across wider areas of tumor tissues treated with relaxin-expressing oncolytic Ad. Moreover, the collagen content of tumor tissues was reduced significantly by relaxin-expressing oncolytic Ad without affecting adjacent normal tissue. A relaxin-expressing oncolytic Ad containing Ad5/35 chimeric fibers in a subcutaneous human A375-mln1 malignant melanoma xenograft model also exhibited increased viral spread and transduction efficiency through the tumor mass and thereby increased anti-tumor efficacy and overall survival in metastatic tumor models (154).

Access of anti-tumor immune cells and their intratumoral infiltration is limited by tumor stroma (19). More specifically, the tumor stroma contributes to tumor immune escape by creating a physical barrier formed by ECM components that restricts direct physical contact between tumor-infiltrating anti-tumor immune cells and cancer cells. As an approach to overcome this limitation, $\mathrm{Li}$ et al. showed that the inducible intratumoral expression of relaxin through the transplantation of mouse hematopoietic stem cells transduced with a relaxin-expressing lentivirus vector led to suppressed tumor growth in an immunocompetent mouse breast cancer model (157). The therapeutic mechanism of the anti-tumor effect is associated with the degradation of tumor stroma mediated by relaxin and enhanced anti-tumor immune responses mediated by better intratumoral infiltration of anti-tumor immune cells. The same investigators also tested whether intratumoral relaxin expression facilitates transplanted anti-tumor $\mathrm{T}$ cells to control tumor growth. In a breast cancer model, they demonstrated that relaxin augmented the efficacy of neu-targeted adoptively transferred $\mathrm{T}$ cells, and improved survival of mice with neu-expressing mammary tumors. At day 33 , in the T cell transplanted group, $25 \%$ of the mice were alive. Combined with relaxin expression, survival increased to $62.5 \%$. Relaxin expression combined with naïve $\mathrm{T}$ cell treatment also increased survival (37.5\%), compared to naïve $\mathrm{T}$ cell treatment alone $(0 \%)$. Better survival of relaxin-expressing mice was due to a higher number of neu-specific $\mathrm{T}$ cells inside the tumor.

Tumor ECM as well as tumor cell density can inhibit diffusional transport of monoclonal antibody therapeutics in tumor tissues. In a study of the monoclonal antibody trastuzumab (Herceptin) penetration, Beyer et al. observed extensive tumor ECM and intercellular junctions in breast cancer patients and xenograft models (156). Therefore, the authors hypothesized that this hinders the access to Her2/neu and/or the intratumoral dispersion of trastuzumab. They showed that hematopoietic stem cell-mediated intratumoral relaxin expression in combination with trastuzumab therapy resulted in a decrease of ECM proteins and a significant delay of tumor growth, indicating that a stem cell-based approach for relaxin expression in tumors facilitates tumor ECM degradation and substantially enhances effectiveness of antibody therapy of cancer.

In all of these studies, relaxin expression did not induce metastasis. In fact, it reversed the spread of tumor cells that normally would metastasize. The latter is in conflict with earlier studies by Silvertown et al. reporting that permanent relaxin overexpression increased in vivo prostate xenograft tumor growth and angiogenesis (165). These results were recently revised by the same group (166). While short-term exposure of tumor cells to relaxin in vitro seems to enhance invasiveness (167), long-term exposure reduces it (168). The general consensus is that relaxin expression alone is not sufficient to induce metastasis, a process that involves dissociation of cells from the primary tumor, enhanced cell motility, and the ability of cells to invade blood vessels and to grow effectively at distant sites (154). 

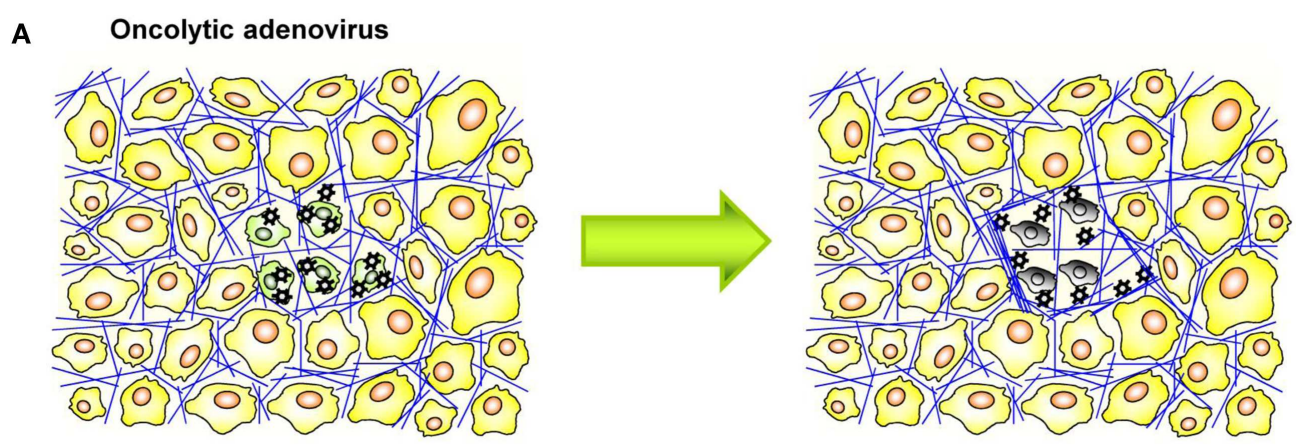

B Relaxin-expressing oncolytic adenovirus
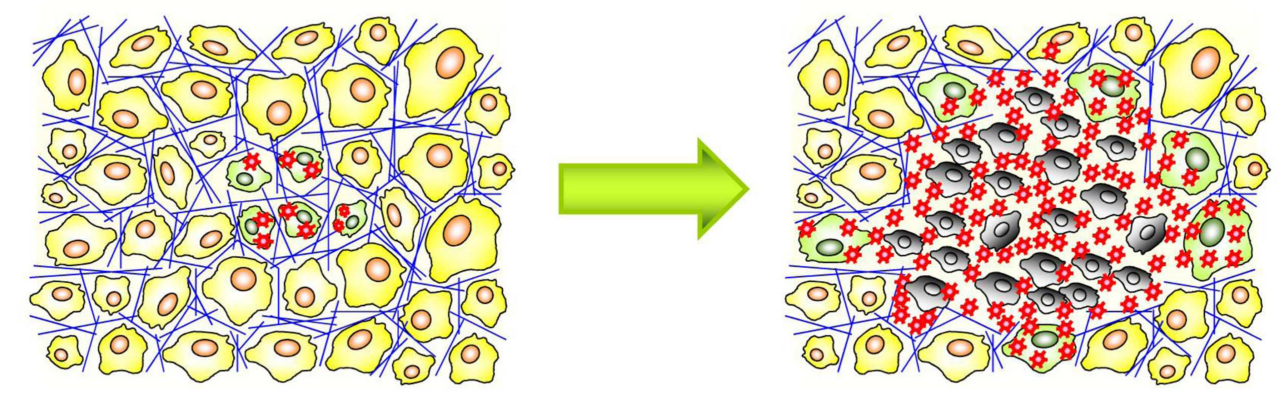

$$
\begin{array}{lll}
\text { OJ Uninfected cancer cell } & \theta \text { Infected cancer cell } & O \text { Dead cancer cell } \\
\not \text { Oncolytic adenovirus } & \not \text { Relaxin-expressing oncolytic adenovirus } & \text { Extracellular matrix }
\end{array}
$$

FIGURE 3 | Therapeutic effect of relaxin-expressing oncolytic adenovirus. (A) ECM acts as a physical barrier in solid tumors, so that interstitial viral penetration and cell-to-cell spread of conventional oncolytic adenoviruses is restricted to the site of administration, leading to limited therapeutic efficacy. (B) Relaxin-expressing oncolytic adenovirus decreases ECM components within a tumor mass and increases its tumor penetration and dispersion, thereby eliciting improved antitumor efficacy.

\section{DECORIN-BASED APPROACHES TO INCREASE DRUG PENETRATION IN SOLID TUMORS}

Decorin, a small leucine-rich proteoglycan consisting of a core protein and a single glycosaminoglycan chain, is a ubiquitous component of ECM. Decorin has an impact on the production of several ECM components. For example, it regulates collagen fibril formation by interacting with collagen fibrils and delaying the lateral assembly of individual triple helical collagen molecules, leading to the reduced diameter of the fibrils (169). Decorin also influences the production of other ECM components by inhibiting the expression of TGF- $\beta$, a key profibrotic growth factor (170). Moreover, decorin has an important role in inducing ECM remodeling through promotion of MMP-1 activity (171). These observations suggest that decorin can modulate tumor ECM production and composition at several levels, and hence has an integral role in degradation and/or downregulation of tumor ECM constituents. Downregulation of TGF- $\beta$ production by decorin could also facilitate anti-tumor immune responses through inhibition of immuno-suppressive $\mathrm{T}$ cells (172). In an oncolytic virotherapy study using decorin, Choi et al. showed that tumor tissue dispersion by decorin-expressing oncolytic Ad was substantially enhanced compared with that of control oncolytic Ad, in tumor spheroids prepared from glioma or breast cancer patients as well as established subcutaneous human glioma xenograft tumors in vivo (158). In this study, decorin-expressing oncolytic Ad significantly reduced ECM components within the tumor tissues while normal tissue adjacent to the tumor was not affected. Decorin-expressing oncolytic Ad therefore led to dramatically increased anti-tumor effect as well as survival benefit in a variety of tumor xenograft models. Importantly, intratumoral administration of decorinexpressing oncolytic Ad to the primary tumor site substantially reduced the formation of B16BL6 melanoma pulmonary metastases in mice, indicating that this approach is capable of inducing a systemic anti-tumor immune response (158).

\section{STRATEGIES TO OPEN EPITHELIAL JUNCTIONS JUNCTION OPENERS}

Various pathogens must first breach the epithelial barrier before gaining access to the body in order to initiate infection. Several mechanisms to disrupt junctional integrity developed in these pathogens, e.g., Clostridium perfringens enterotoxin removes claudins- 3 and -4 from tight junctions to facilitate bacterial invasion (173). Also, zona occludens toxin (Zot) is produced by Vibrio cholerae strains and possesses the ability to reversibly modify 
intestinal epithelial tight junctions, granting the passage of macromolecules through mucosal barriers (174). Notably Cox et al. have shown that Zot increases the transport of drugs with low bioavailability (e.g., paclitaxel, doxorubicin, acyclovir, and cyclosporin A) up to 30-fold (175). Additionally, oncoproteins encoded by human papillomavirus (HPV), human Ad, and human T-lymphotropic virus 1 (HTLV-1) can transiently open tight junctions by the mislocalization of the tight junction protein $\mathrm{ZO}-1$, thereby enhancing paracellular permeability in epithelial cells (176). It is intriguing that several viruses target epithelial junction protein to achieve infection of and dissemination in epithelial tissues. Most species of human adenoviruses (except species B) binds to the CAR. CAR is a tight junction protein. A number of studies have demonstrated that during replication of Ad5, excess production of fiber or fiber/penton base complexes results in the disruption of epithelial junctions either by interfering with CAR dimerization or by triggering intracellular signaling that leads to reorganization of intercellular junctions $(177,178)$. Measles virus uses the adherence junction protein nectin 4 (179). Finally, we have shown that species B adenoviruses target the desmosomal junction protein DSG2. To date, however, there are no epithelial junction openers that are being used for cancer therapy. A number of chemical detergents, surfactants, calcium-chelating agents, and phospholipids have been used to increase drug absorption through the gastrointestinal (GI) tract epithelium (180). Recently, Kytogenics Pharmaceuticals, Inc., has developed a tight junction opener based on chitosan derivatives. It is thought to act by electronegative forces applied to tight junction proteins. However, all of these agents act indiscriminately to mechanically disrupt junctions and cannot be applied systemically without major toxic side effects.

\section{AD SEROTYPE 3 DERIVED JUNCTION OPENER J0-1}

Human Ads have been classified into 7 species (A to G) currently containing 57 serotypes. Wang et al. recently reported that a group of human Ads uses DSG2 as a receptor for infection (181). Among DSG2-targeting viruses is serotype 3 (Ad3). Ad3 is able to efficiently breach the epithelial barrier in the airway tract and infect airway epithelial cells. This is achieved by the binding of Ad3 to DSG2, and subsequent intracellular signaling that results in transient opening of tight junctions between epithelial cells. Wang et al. have capitalized on this mechanism and created a recombinant protein that contains the minimal structural domains from $\mathrm{Ad} 3$ that are required for opening of the intercellular junctions in epithelial tumors. This protein is called "junction opener 1" or "JO-1." JO-1 is a self-dimerizing recombinant protein derived from the Ad3 fiber (182). JO-1 has a molecular weight of approximately $60 \mathrm{kDa}$ (Figure 4A). It can be easily produced in E. coli and purified by affinity chromatography. JO-1 binding to and clustering of DSG2 triggers EMT that results in transient opening of epithelial junctions, in polarized epithelial cancer cells in vitro (Figures $4 \mathrm{~B}, \mathrm{C}$ ) and in vivo, in mouse models with epithelial tumors. Wang et al. have shown in over 25 xenograft tumor models that the intravenous injection of JO-1 increased the efficacy of cancer therapies, including many different monoclonal antibodies and chemotherapy drugs, in a broad range of epithelial tumors. Further studies showed that the effective doses of chemotherapy can be reduced when the chemotherapy drugs are combined with
JO-1. Finally, studies have demonstrated that combining JO-1 with chemotherapy drugs markedly reduced the toxic side effects of chemotherapy. The application of JO-1 was safe and well-tolerated in toxicology studies carried out in human DSG2-transgenic mice and macaques $(109,181)$.

\section{Mechanism of J0-1-mediated junction opening}

Wang et al. suggested that at least two mechanisms are involved in JO-1-mediated opening of tight junctions: DSG2 cleavage/internalization and EMT-like intracellular signaling. Epithelial cells are linked to each other by homodimers of DSG2. Studies in vitro and in xenograft models have shown that the DSG2 ECD is cleaved upon binding of JO-1, which results in DSG2 internalization (109). On the other hand, a series of data indicate that Ad3 binding triggers EMT-like signaling, which most likely involves the intracellular domain (ICD) of DSG2. Using mRNA expression arrays and qRT-PCR, Wang et al. found $12 \mathrm{~h}$ after incubation of polarized breast cancer epithelial cells with a JO-1-like ligand that 430 genes were upregulated and 352 genes were downregulated compared to incubation with a control protein (181). mRNA expression profiling revealed the activation of pathways involved in EMT (MAPK/ERK, adherens junctions, focal adhesion, and regulation of actin cytoskeleton signaling). Further studies showed an increase in PI3K and MAPK/ERK1/2 phosphorylation within $1 \mathrm{~h}$ after incubation with Ad type 3 pento-dodecahedral particles or JO-1 (109, 181). PI3K and MAPK/ERK1/2 activation was significantly decreased in cells in which DSG2 expression was suppressed by siRNA. Beyer et al. also found that subsequently to MAPK and $\mathrm{PI} 3 \mathrm{~K}$ activation, the protein levels of E-cadherin, a key junction protein, decreased in epithelial cells, indicating a down-regulation of gene expression of junction proteins (109).

\section{J0-1 increases the efficacy of cancer therapy by monoclonal antibodies and chemotherapy drugs}

Beyer et al. have also shown in mouse xenograft tumor models that the i.v. administration of JO-1-mediated junction opening in epithelial tumors (183). The changes triggered by JO-1 were detectable within $1 \mathrm{~h}$ after its i.v. injection. This, subsequently, enabled the increased intratumoral penetration of the anti-Her2/neu mAb trastuzumab (109). These biological effects of JO-1 translated into an increased therapeutic efficacy of several $\mathrm{mAbs}$, including trastuzumab and cetuximab, in xenograft tumor models, e.g., models of colon, breast, gastric, lung, and ovarian cancer (109). JO-1 co-administration also enhanced the therapeutic efficacy of several chemotherapy drugs, including PEGylated liposomal doxorubicin (PLD or Doxil $\left.{ }^{\circledR}\right)$, paclitaxel $\left(\operatorname{Taxol}^{\circledR}\right)$, nanoparticle albumin bound paclitaxel (Abraxane ${ }^{\circledR}$ ), and irinotecan (Camptosar ${ }^{\circledR}$ ) in tumor xenograft models of breast, lung, and prostate cancer (183). Furthermore, chemotherapy doses could be decreased without compromising the anti-tumor effects due to JO-1 co-therapy. This also provided protective effects to normal tissues (183). For example, we showed that the ability of JO-1 to open intercellular junctions in tumors increased the uptake and amount of chemotherapeutics in the tumor environment (Figures 5A-C). This then resulted in reduced drug levels in normal tissues, thereby providing a larger therapeutic window. Immunofluorescence analysis of tissue sections also revealed higher levels of PLD in tumors of JO-1 + PLD treated mice 
A
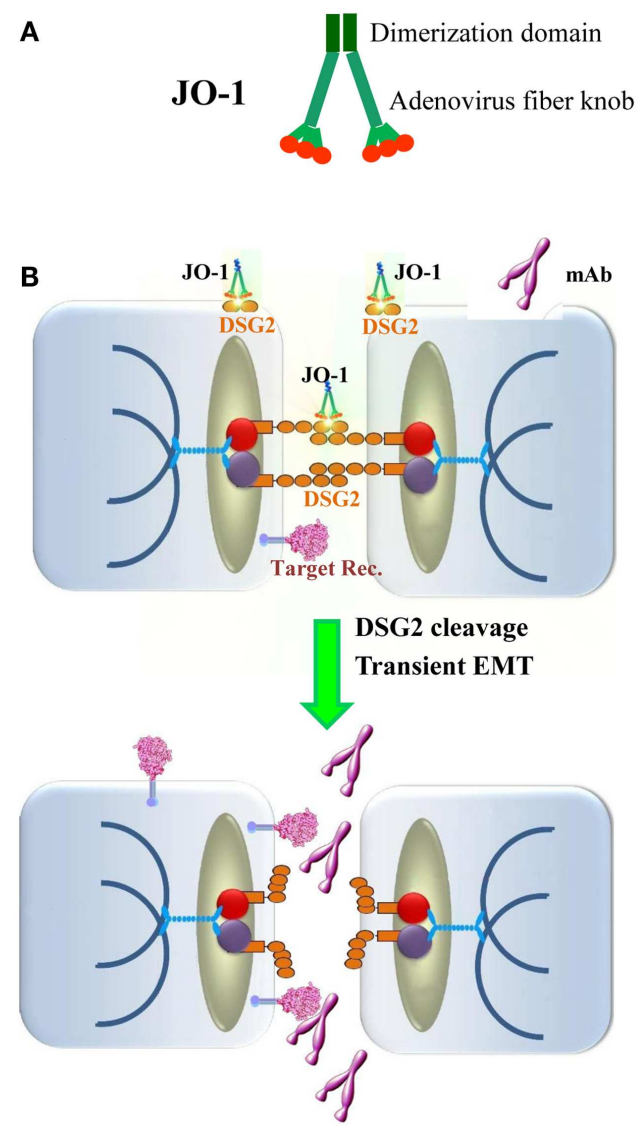

FIGURE 4 | Junction opener 1 (JO-1). (A) Schematic structure of JO-1 The Ad serotype 3 fiber knob domain and one fiber shaft motif was fused through a flexible linker to a homodimerizing K-coil domain (182). The protein is self-dimerizing and can be purified by His-Ni-NTA affinity chromatography. (B) Mode of action. JO-1 binds with picomolar avidity to DSG2. In epithelial cancer cells, DSG2 is overexpressed and exposed on the cell surface with preferential localization to desmosomes. JO-1 binding to DSG2 triggers cleavage of DSG2 dimers between neighboring cells and the transient activation of EMT pathways. This triggers junction opening and relocalization of target receptors that are often trapped in epithelial

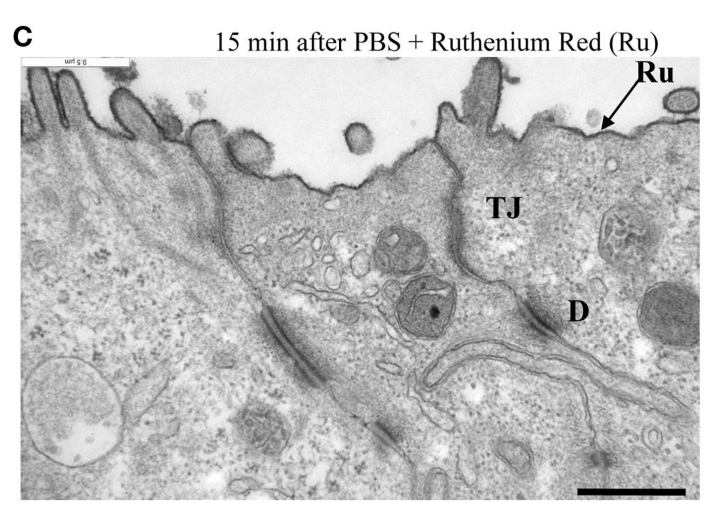

15 min after JO-1 + Ruthenium Red

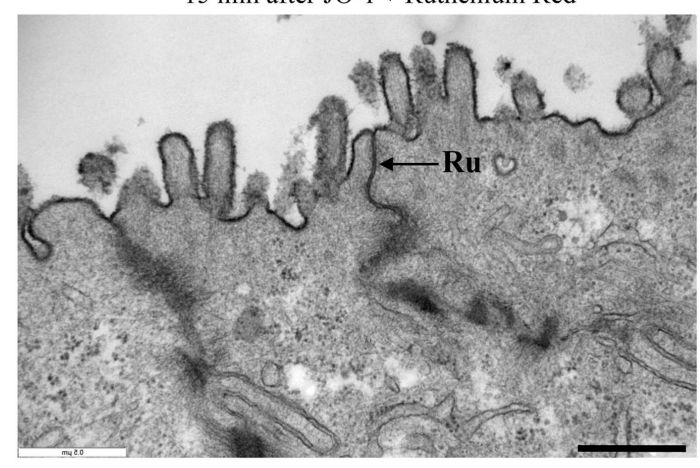

junctions. Junction opening allows for access of drugs (for example mAbs) to their target receptors. (C) Transmission electron microscopy of junctional areas of T84 cells. Cells were either treated with PBS (upper panel) or JO-1 (lower panel) for $1 \mathrm{~h}$ on ice, washed, and then incubated for $15 \mathrm{~min}$ at $37^{\circ} \mathrm{C}$. At this time, the electron-dense dye ruthenium red (Ru) (1) was added together with the fixative. If tight junctions labove the desmosomes) are closed, the dye only stains the apical membrane (black line). If tight junctions are open, the dye penetrates between the cells and stains the baso-lateral membrane. JO-1 also mediates the partial dissociation of desmosomes (D). The scale bar is $0.5 \mu \mathrm{m}$. compared to mice treated with PLD alone. In these animals, PLD is found to be more broadly distributed over a greater distance from blood vessels, suggesting better intratumoral penetration and absorption by tumor tissue (Figure 5B). Using an ELISA to measure PEGylated compounds in tissues (184), we found more PLD in tumors and less in normal tissues of mice that received JO-1 prior to i.v. PLD injection (Figure 5C). Better intratumoral penetration and accumulation of PLD after JO-1-mediated junction opening, resulted in enhanced therapeutic efficacy of PLD chemotherapy. This was shown in a model with mammary fat pad tumors derived from primary ovarian cancer cells (obtained from a patient biopsy) (135). This cell line was nearly resistant to PLD injected intravenously at a dose that corresponds to PLD doses used in patients. Importantly, JO-1 pre-treatment significantly improved PLD therapy (Figure 5D). JO-1 also relieved adverse side effects from PLD treatment, e.g., liver enzymes (AST, ALT, and alkaline phosphatase) were significantly decreased in animals treated with JO-1 and PLD compared to mice treated with PLD alone. Mice that received JO-1 injections also had less severe tissue damage in the bone marrow and intestine caused by PLD treatment (183).

\section{Relocalization of target receptors}

In breast cancer xenograft sections and in cultured breast cancer cells, Beyer et al. found co-staining of Her2/neu and the adherens junction protein claudin 7 (183). Confocal microscopy of breast cancer BT474 cells confirmed the trapping of Her2/neu in lateral junctions. Incubation of the Her2/neu positive breast cancer cell lines BT474 or HCC1954 with JO-1 changed the composition of the lateral epithelial junctions within $1 \mathrm{~h}$. As a result of this, Her2/neu staining at the cells surface became more intense, while it faded in areas distal of the cell surface. This suggests that JO-1-mediated junction opening triggered a translocation of Her2/neu from lateral membranes to the cell surface. 


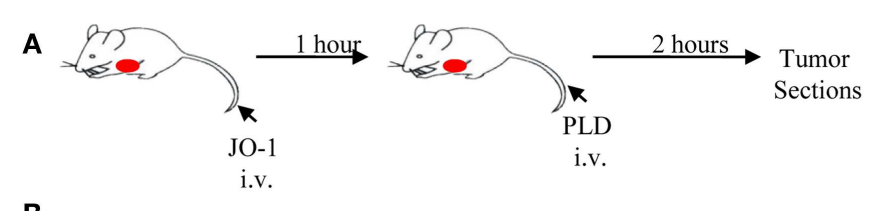

B
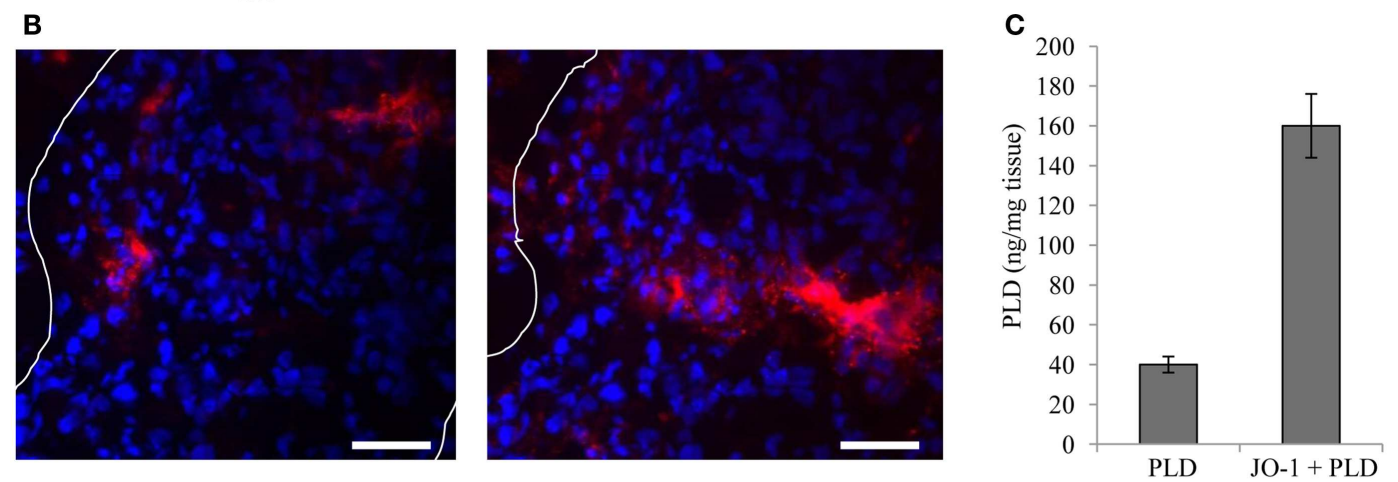

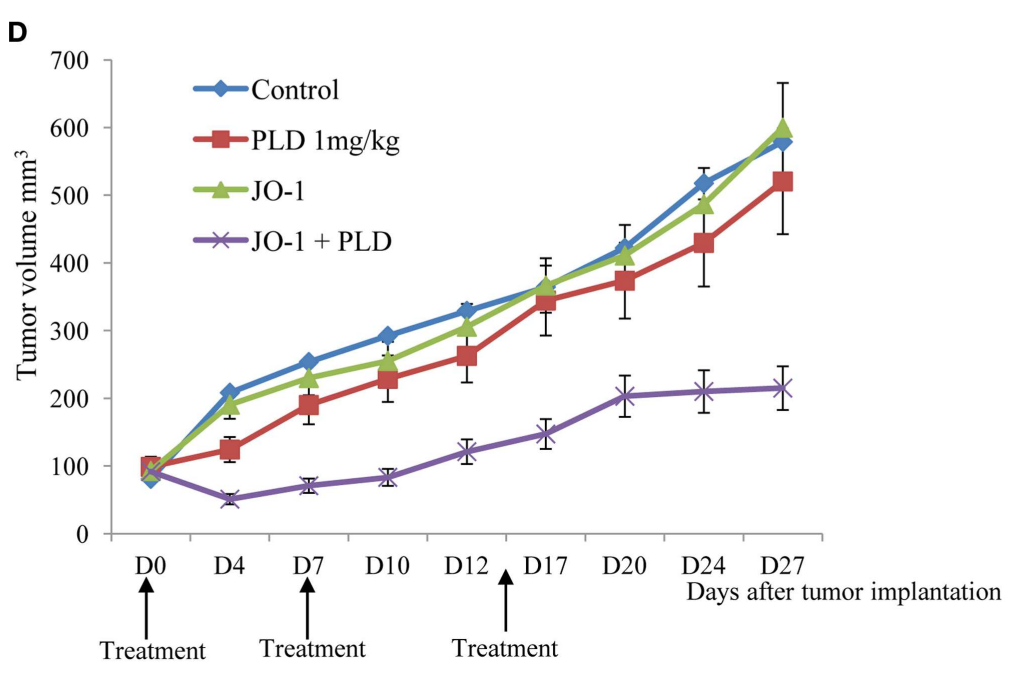

FIGURE 5 | Junction opener 1 increases tumor penetration and efficacy of PEGylated liposomal doxorubicin (PLD)/Doxil ${ }^{\mathrm{TM}}$. Studies were performed in mice with mammary fat pad tumors derived from ovc316 cells $(135,206)$. Ovc316 cells are Her2/neu positive epithelial tumor cells derived from an ovarian cancer biopsy. (A) Scheme of experiment on tumor penetration of PLD. Mice were intravenously injected with PBS or JO-1 $(2 \mathrm{mg} / \mathrm{kg}$ ) followed by PLD or PBS $1 \mathrm{~h}$ later. Two hours after PBS or PLD injection, mice were sacrificed and tumors harvested. (B)
Immunofluorescence analysis for PLD on tumor sections with anti-PEG antibodies. PLT appears in red. The scale bar is $20 \mu \mathrm{m}$. Notably, free PEG is poorly detected by ELISA or immunohistochemistry (184). (C) PLD concentrations in tumors measured by ELISA ( $N=3$ ). (D) Therapy study in mice with ovc316 tumors. Treatment was started when tumors reached a volume of $100 \mathrm{~mm}^{3}$ (D0). Mice were injected intravenously with $2 \mathrm{mg} / \mathrm{kg}$ JO-1 or PBS, followed by an intravenous injection of PLD $(1 \mathrm{mg} / \mathrm{kg})$ or PBS $1 \mathrm{~h}$ later. Treatment was repeated weekly $(N=5)$.

\section{Tumor-specificity of J0-1 action}

Junction opener 1 does not efficiently bind to mouse (185), hamster, or dog DSG2 (André Lieber, unpublished data). To perform efficacy and safety studies in a small animal model, we generated human DSG2-transgenic mice that expressed human DSG2 at a level and in a pattern similar to humans (185). Using the hDSG2transgenic mouse model with syngeneic hDSG2 ${ }^{\text {high }}$ tumors, we demonstrated that JO-1 predominantly accumulates in tumors (183). This could be explained by either one of the following factors: (i) the overexpression of DSG2 by tumor cells, (ii) better accessibility of DSG2 on tumor cells due to a lack of strict cell polarization compared to DSG2-expressing normal epithelial cells, or (iii) a high degree of vascularization and vascular permeability in tumors.

\section{Toxic side effects and immunogenicity}

The i.v. injection of JO-1 at a dose of $2 \mathrm{mg} / \mathrm{kg}$ into hDSG2transgenic mice had no observed adverse side effects, except for mild, transient diarrhea. There were also no abnormalities found in laboratory parameters as well as histopathological studies of tissues. We speculate that this is due to the fact that DSG2 in tissues, other than the tumor and a subset of epithelial cells in the intestine/colon, is not accessible to i.v. injected JO-1. The hDSG2-transgenic mouse model was also used to obtain biodistribution and pharmacokinetics data for JO-1 (183).

Recently, we started safety studies with JO-1 in macaques. So far, we injected two animals intravenously with JO-1 at a dose of $0.6 \mathrm{mg} / \mathrm{kg}$ and performed a full necropsy 3 days later. Behavior and health was normal in both animals. In blood and tissue 
analyses, we did not find hematological or histological abnormalities, except for a mild inflammation in the small intestine. JO-1 binding to DSG2 on tumor cells triggers pathways involved in EMT, a process which, as mentioned above, has been associated with tumor metastasis. Over 20 in vivo studies conducted with JO1 combined with a range of cancer therapeutics in various different cancers with long-term follow-up, have not provided any evidence of metastases (183). Transient activation of the EMT pathway is only one of many steps required for tumor metastasis. Detachment of tumor cells from epithelial cancers and their subsequent migration is only possible after long-term crosstalk between malignant cells and the tumor microenvironment, resulting in changes in the tumor stroma and phenotypic reprograming of epithelial cells into mesenchymal cells (186).

Junction opener 1 is a protein derived form $\mathrm{Ad} 3$ and therefore potentially immunogenic. This might not be a critical issue if JO-1 is used in combination with chemotherapy, which suppresses immune responses (187-189). In addition, Beyer et al. have shown that JO-1 remains active in vitro and in vivo, even in the presence of anti-JO-1 antibodies generated by the JO-1 vaccination of mice (183). This may be due to the fact that JO-1 binds to DSG2 with a very high avidity, thus potentially disrupting the complexes between JO-1 and antibodies against JO-1. Notably, JO- 1 is a dimer of a trimeric fiber knob, which contributes to the picomolar avidity to DSG2 (182). Wang et al. performed repeated injections of JO-1 in an immunocompetent hDSG2 mouse tumor model to test the effect of anti-JO-1 antibodies on the therapeutic efficacy of JO-1 (185). Importantly JO-1 had an enhancing effect on PLD therapy after repeated JO-1 pre-treatment, demonstrating that JO- 1 continues to be effective after multiple treatment cycles, even in the presence of detectable antibodies.

\section{STRATEGIES TO REMODEL THE TUMOR STROMA THROUGH TARGETING OF TAMs}

As outlined in chapter 1.2, bone marrow-derived cells, including TAMs, have a pro-tumor effect, in part through the stimulation of ECM protein synthesis, which in turn blocks intratumoral penetration of drugs. Therefore, killing of TAMs should, theoretically, increase the intratumoral penetration and accumulation of anti-cancer drugs. TAM depletion results in tumor growth suppression. This has been shown in animal models of cancer by using transgenic mice $(190,191)$, clodronate liposome-depletion of macrophages (192), DNA vaccination against macrophages (193), and neutralizing antibodies against macrophage chemoattractants (194). For example, Zeisberger et al. showed that combining macrophage depletion with antibody therapy greatly decreased the tumor size (195). Furthermore, a recent study showed that TAM targeting by inhibiting either the myeloid cell receptors colony stimulating factor-1 receptor (CSF1R) or chemokine (C$\mathrm{C}$ motif) receptor 2 (CCR2) decreased the number of TICs in pancreatic tumors, improved chemotherapeutic efficacy, inhibited metastasis, and increased anti-tumor T cell responses (196). Overall these studies showed that decreasing the number of TAMs in the tumor stroma effectively altered the tumor microenvironment and markedly suppressed tumor growth and metastasis. Targeting TAMs did not interfere with the biological functions of M1 macrophages, including cytotoxicity and antigen presentation.
We are currently attempting to deliver a suicide gene to TAMs using TAM targeting Ad vectors or the HSC-based approach described for relaxin gene delivery (157). To restrict suicide gene expression to TAMs we utilized a miRNA-based system that avoids transgene expression in other myeloid cells. As a therapeutic gene for killing TAMs, we are currently focusing on the enzyme cytosine deaminase, which converts the prodrug 5-Flurocytosine (5-FC) to the active chemotherapeutic agent 5-Fluorouracil (5-FU) (197). Toxic 5-FU and metabolites diffuse out of TAMs to surrounding cells killing TAMs as well as neighboring dividing tumor cells.

\section{STRATEGIES TO INHIBIT EMT TO REMODEL THE TUMOR STROMA}

As outlined above, EMT in solid tumors promotes the expression of several ECM proteins and thus blocks penetration of anticancer drugs. This give a rationale for inhibiting EMT processes in epithelial tumors. Accumulating knowledge about EMT pathways in solid tumors led to the development of EMT targeted therapies (198). Classically, such treatment strategies concentrate on the blockage of ATP-binding sites in affected kinases using small molecule inhibitors, as the RTK inhibitor Gefitinib for treatment of non-small cell lung cancer with activated EGFR mutation (199). While originally designed for their anti-proliferative effect on cancer cells, it was also shown that such molecules can influence the EMT status. In a cell-based screening of 267 small molecules, several compounds targeting ALK5, MEK, and SRC kinases were identified as potent inhibitors of EMT induced by EGF, HGF, and IGF-1 (200). It was also shown that counteracting TGF- $\beta$ induced EMT by treatment with troglitazone or knockdown of Smad3 in tumor cells can significantly inhibit experimental metastasis in mice (201). Furthermore, targeting early specific EMT events, like the degradation of epithelial basement membranes, can be a successful strategy, as shown in renal interstitial fibrosis. Deficiency of plasminogen activator (tPA), which is a potent activator of MMP-9, resulted in stable epithelial basement membranes and inhibition of EMT (202). Furthermore, studies involving the expression of pro-epithelial factors such as BMP-7 and Dkk, have demonstrated the inhibition of EMT and consequent CSC induction as well as metastasis in colon and prostate cancer models (203, 204). In pioneering work to understand the complexity underlying EMT induction, Scheel and colleagues showed recently that canonical and non-canonical Wnt signaling cooperate with TGF$\beta$ in order to initiate EMT in breast cancer (205). Consequently, a series of commercial or experimental Wnt-pathway inhibitors counteracted EMT. In summary, similar pathways promote therapy resistance, EMT, CSCs, and metastasis. This gives a rationale to inhibit processes that induce the mesenchymal phenotype of cancer cells. Clearly, inhibition of EMT must target a variety of pathways and should only be considered when combined therapy is applied that targets proliferating cells.

\section{CONCLUSION}

Most solid tumors are derived from epithelial cells. Malignant tumor cells actively protect themselves from host-immune responses and anti-cancer therapeutics by creating physical barriers that prevent the intratumoral penetration and contact to malignant cells. This is achieved by the production of cytokines 
and chemokines that attract fibroblasts and myeloid cells into the tumor and differentiate them into cells that support tumor growth and produce ECM proteins that shield nests of malignant tumor cells. Furthermore, although malignant cells display a high degree of dedifferentiation, they maintain epithelial junctions that seal the paracellular space between tumor cells and block access to tumor antigens or target receptors. Tumor ECM and epithelial junctions represent the most basic mechanisms that create resistance to cancer treatment. Because of their importance to the tumor, they also represent an "Achilles' heel" that can be used for cancer therapy. Removal of these barriers will either directly negatively affect tumor cells or facilitate anti-tumor immune responses and drug treatment, through better intratumoral penetration and accessibility of target cells. A number of experimental approaches are aimed toward the transient degradation or downregulation of ECM proteins using injection of ECM-degrading enzymes into the tumor or their intratumoral

\section{REFERENCES}

1. Bissell MJ, Radisky D. Putting tumours in context. Nat Rev Cancer (2001) 1(1):46-54. doi:10. 1038/35094059

2. Mueller MM, Fusenig NE. Friends or foes - bipolar effects of the tumour stroma in cancer. Nat Rev Cancer (2004) 4(11):839-49. doi: $10.1038 / \mathrm{nrcl} 477$

3. Bhowmick NA, Neilson EG, Moses HL. Stromal fibroblasts in cancer initiation and progression. Nature (2004) 432(7015):332-7. doi:10. 1038/nature03096

4. Wiseman BS, Werb Z. Stromal effects on mammary gland development and breast cancer. Science (2002) 296(5570):1046-9. doi:10. 1126/science.1067431

5. Stickens D, Behonick DJ, Ortega N, Heyer B, Hartenstein B, $\mathrm{Yu}$ Y, et al. Altered endochondral bone development in matrix metalloproteinase 13deficient mice. Development (2004) 131(23):5883-95. doi: 10.1242/dev.01461

6. Rebustini IT, Myers C, Lassiter KS, Surmak A, Szabova L, Holmbeck K, et al. MT2MMP-dependent release of collagen IV NC1 domains regulates submandibular gland branching morphogenesis. Dev Cell (2009) 17(4):482-93. doi:10.1016/ j.devcel.2009.07.016

7. Puri S, Hebrok M. Cellular plasticity within the pancreas - lessons learned from development. Dev Cell (2010) 18(3):342-56. doi:10. 1016/j.devcel.2010.02.005

8. Tlsty TD, Coussens LM. Tumor stroma and regulation of cancer development. Annu Rev Pathol (2006) 1:119-50. doi:10.1146/ annurev.pathol.1.110304.100224
9. Feig C, Gopinathan A, Neesse A, Chan DS, Cook N, Tuveson DA. The pancreas cancer microenvironment. Clin Cancer Res (2012) 18(16):4266-76. doi: 10.1158/1078-0432.CCR-11-3114

10. Yun CO. Overcoming the extracellular matrix barrier to improve intratumoral spread and therapeutic potential of oncolytic virotherapy. Curr Opin Mol Ther (2008) 10(4):356-61.

11. Egeblad M, Nakasone ES, Werb Z. Tumors as organs: complex tissues that interface with the entire organism. Dev Cell (2010) 18(6):884-901. doi: 10.1016/j.devcel.2010.05.012

12. Cox TR, Erler JT. Remodeling and homeostasis of the extracellular matrix: implications for fibrotic diseases and cancer. Dis Model 1242/dmm.004077

13. Lu P, Weaver VM, Werb Z. The extracellular matrix: a dynamic niche in cancer progression. J Cell Biol (2012) 196(4):395-406. doi: 10.1083/jcb.201102147

14. Zhu GG, Risteli L, Makinen M, Risteli J, Kauppila A, Stenback F. Immunohistochemical study of type I collagen and type I pNcollagen in benign and malignant ovarian neoplasms. Cancer (1995) 75(4):1010-7. doi:10.1002/10970142(19950215)75:4<010::AIDCNCR2820750417>3.0.CO;2-O

15. Ronnov-Jessen L, Petersen OW, Bissell MJ. Cellular changes involved in conversion of normal to malignant breast: importance of the stromal reaction. Physiol Rev (1996) 76(1):69-125.

16. Kauppila S, Stenback F, Risteli J, Jukkola A, Risteli L. Mech (2011) 4(2):165-78. doi:10.

expression after viral- or stem cell-based gene transfer. We recently finished a phase I clinical trial with a relaxin-expressing oncolytic Ad in patients with recurrent cancer, demonstrating a clinical benefit with a good safety profile. Furthermore, we are focusing on the clinical development of a recombinant epithelial junction opener to be used in combination with Doxil chemotherapy in ovarian cancer patients. Other approaches to overcome physical barriers in tumors are at a less advanced stage. These approaches attempt to indirectly decrease tumor-associated ECM by killing tumor stromal cells that produce ECM proteins (e.g., tumor-associated fibroblasts or macrophages). ECM production and epithelial junctions can also be targeted through influencing signaling pathways in tumor cells, specifically pathways involved in the regulation of EMT/MET and hypoxia. In conclusion, there is an increasing arsenal of approaches that can be used to enhance the efficacy of more classical cancer therapeutics and overcome treatment resistance.

Aberrant type I and type III collagen gene expression in human breast cancer in vivo. J Pathol (1998) 186(3):262$8 . \quad$ doi:10.1002/(SICI)10969896(1998110)186:3<262::AIDPATH191>3.0.CO;2-3

17. Huijbers IJ, Iravani M, Popov S, Robertson D, Al-Sarraj S, Jones $\mathrm{C}$, et al. A role for fibrillar collagen deposition and the collagen internalization receptor endo 180 in glioma invasion. PLoS ONE (2010) 5(3):e9808. doi:10.1371/ journal.pone.0009808

18. Pluen A, Boucher Y, Ramanujan S, McKee TD, Gohongi T, di Tomaso $\mathrm{E}$, et al. Role of tumor-host interactions in interstitial diffusion of macromolecules: cranial vs. subcutaneous tumors. Proc Natl Acad Sci U S A (2001) 98(8):4628-33. doi: $10.1073 /$ pnas.081626898

19. Jain RK. Vascular and interstitial barriers to delivery of therapeutic agents in tumors. Cancer Metastasis Rev (1990) 9(3):253-66. doi: 10.1007/BF00046364

20. Fechner H, Haack A, Wang $H$, Wang X, Eizema K, Pauschinger $M$, et al. Expression of coxsackie adenovirus receptor and alphavintegrin does not correlate with adenovector targeting in vivo indicating anatomical vector barriers. Gene Ther (1999) 6(9):1520-35. doi:10.1038/sj.gt.3301030

21. Li ZY, Ni S, Yang X, Kiviat $\mathrm{N}$, Lieber A. Xenograft models for liver metastasis: relationship between tumor morphology and adenovirus vector transduction. Mol Ther (2004) 9(5):650-7. doi: 10.1016/j.ymthe.2004.01.021

22. Kuh HJ, Jang SH, Wientjes $M G$, Weaver JR, Au JL. Determinants of paclitaxel penetration and accumulation in human solid tumor. I Pharmacol Exp Ther (1999) 290(2):871-80.

23. Gorlach A, Herter P, Hentschel H, Frosch PJ, Acker H. Effects of nIFN beta and rIFN gamma on growth and morphology of two human melanoma cell lines: comparison between two- and threedimensional culture. Int J Cancer (1994) 56(2):249-54. doi:10.1002/ ijc. 2910560218

24. Wenning LA, Murphy RM. Coupled cellular trafficking and diffusional limitations in delivery of immunotoxins to multicell tumor spheroids. Biotechnol Bioeng (1999) 62(5):56275 doi:10.1002/(SICI)10970290(19990305)62:5<562::AIDBIT8>3.0.CO;2-4

25. Strauss R, Sova P, Liu Y, Li ZY, Tuve S, Pritchard D, et al. Epithelial phenotype confers resistance of ovarian cancer cells to oncolytic adenoviruses. Cancer Res (2009) 69(12):5115-25. doi:10. 1158/0008-5472.CAN-09-0645

26. Levental KR, Yu H, Kass L, Lakins JN, Egeblad M, Erler JT, et al. Matrix crosslinking forces tumor progression by enhancing integrin signaling. Cell (2009) 139(5):891-906. doi: 10.1016/j.cell.2009.10.027

27. Lopez JI, Kang I, You WK, McDonald DM, Weaver VM. In situ force mapping of mammary gland transformation. Integr Biol (Camb) (2011) 3(9):910-21. doi:10.1039/ clib00043h

28. Netti PA, Berk DA, Swartz MA, Grodzinsky AJ, Jain RK. Role of extracellular matrix assembly in interstitial transport in solid tumors. Cancer Res (2000) 60(9):2497-503. 
29. Brown EB, Boucher Y, Nasser S, Jain RK. Measurement of macromolecular diffusion coefficients in human tumors. Microvasc Res (2004) 67(3):231-6. doi:10.1016/j. mvr.2004.02.001

30. Heldin $\mathrm{CH}$, Rubin K, Pietras $\mathrm{K}$, Ostman A. High interstitial fluid pressure - an obstacle in cancer therapy. Nat Rev Cancer (2004) 4(10):806-13. doi:10.1038/ nrc1456

31. Orimo A, Gupta PB, Sgroi DC, Arenzana-Seisdedos F, Delaunay T, Naeem R, et al. Stromal fibroblasts present in invasive human breast carcinomas promote tumor growth and angiogenesis through elevated SDF-1/CXCL12 secretion. Cell (2005) 121(3):335-48. doi:10. 1016/j.cell.2005.02.034

32. Li H, Fan X, Houghton J. Tumor microenvironment: the role of the tumor stroma in cancer. $J$ Cell Biochem (2007) 101(4):80515. doi:10.1002/jcb.21159

33. Leonardi GC, Candido S, Cervello M, Nicolosi D, Raiti F, Travali $\mathrm{S}$, et al. The tumor microenvironment in hepatocellular carcinoma (review). Int $\mathrm{J}$ Oncol (2012) 40(6):1733-47. doi: 10.3892/ijo.2012.1408

34. Kalluri R, Zeisberg M. Fibroblasts in cancer. Nat Rev Cancer (2006) 6(5):392-401. doi:10.1038/ nrc1877

35. Ostman A, Augsten M. Cancerassociated fibroblasts and tumor growth - bystanders turning into key players. Curr Opin Genet Dev (2009) 19(1):67-73. doi:10.1016/j. gde.2009.01.003

36. Elenbaas B, Weinberg RA. Heterotypic signaling between epithelial tumor cells and fibroblasts in carcinoma formation. Exp Cell Res (2001) 264(1):169-84. doi:10. 1006/excr.2000.5133

37. Coussens LM, Werb Z. Inflammation and cancer. Nature (2002) 420(6917):860-7. doi: 10.1038 /nature01322

38. Dean JP, Nelson PS. Profiling influences of senescent and aged fibroblasts on prostate carcinogenesis. $\mathrm{Br}$ J Cancer (2008) 98(2):245-9. doi: 10.1038/sj.bjc.6604087

39. Gabbiani G. The myofibroblast in wound healing and fibrocontractive diseases. $J$ Pathol (2003) 200(4):500-3. doi: 10.1002/path.1427

40. Barsky SH, Green WR, Grotendorst GR, Liotta LA. Desmoplastic breast carcinoma as a source of human myofibroblasts. Am J Pathol (1984) 115(3):329-33.
41. Pietras K, Ostman A. Hallmarks of cancer: interactions with the tumor stroma. Exp Cell Res (2010) 316(8):1324-31. doi:10. 1016/j.yexcr.2010.02.045

42. De Wever O, Nguyen QD, Van Hoorde L, Bracke M, Bruyneel E, Gespach C, et al. Tenascin-C and SF/HGF produced by myofibroblasts in vitro provide convergent pro-invasive signals to human colon cancer cells through RhoA and Rac. FASEB J (2004) 18(9):1016-8.

43. Li G, Satyamoorthy K, Meier F, Berking C, Bogenrieder T, Herlyn $M$. Function and regulation of melanoma-stromal fibroblast interactions: when seeds meet soil. Oncogene (2003) 22(20):3162-71. doi:10.1038/sj.onc. 1206455

44. Sato T, Sakai T, Noguchi Y, Takita M, Hirakawa S, Ito A. Tumorstromal cell contact promotes invasion of human uterine cervical carcinoma cells by augmenting the expression and activation of stromal matrix metalloproteinases. Gynecol Oncol (2004) 92(1):47-56. doi:10.1016/j.ygyno. 2003.09.012

45. Orimo A, Tomioka Y, Shimizu Y, Sato M, Oigawa S, Kamata K, et al. Cancer-associated myofibroblasts possess various factors to promote endometrial tumor progression. Clin Cancer Res (2001) 7(10):3097-105.

46. Lewis CE, Pollard JW. Distinct role of macrophages in different tumor microenvironments. Cancer Res (2006) 66(2):605-12. doi:10.1158/ 0008-5472.CAN-05-4005

47. Ueno T, Toi M, Saji H, Muta M, Bando H, Kuroi K, et al. Significance of macrophage chemoattractant protein-1 in macrophage recruitment, angiogenesis, and survival in human breast cancer. Clin Cancer Res (2000) 6(8):32829.

48. Lin EY, Pollard JW. Role of infiltrated leucocytes in tumour growth and spread. $\mathrm{Br} J \mathrm{Can}$ cer (2004) 90(11):2053-8. doi:10. 1038/sj.bjc.6601705

49. Balkwill F, Charles KA, Mantovani A. Smoldering and polarized inflammation in the initiation and promotion of malignant disease. Cancer Cell (2005) 7(3):2117. doi:10.1016/j.ccr.2005.02.013

50. Lin EY, Pollard JW. Tumorassociated macrophages press the angiogenic switch in breast cancer. Cancer Res (2007) 67(11):5064-6. doi:10.1158/0008-5472.CAN-070912
51. van der Bij GJ, Oosterling SJ, Meijer S, Beelen RH, van Egmond M. The role of macrophages in tumor development. Cell Oncol (2005) 27(4):203-13

52. Lewis C, Murdoch C. Macrophage responses to hypoxia: implications for tumor progression and anti-cancer therapies. Am Pathol (2005) 167(3):627-35. doi: 10.1016/S0002-9440(10)62038-X

53. Barbera-Guillem E, Nyhus JK, Wolford CC, Friece CR, Sampsel JW. Vascular endothelial growth factor secretion by tumor-infiltrating macrophages essentially supports tumor angiogenesis, and IgG immune complexes potentiate the process. Cancer Res (2002) 62(23):7042-9.

54. Pollard JW. Tumour-educated macrophages promote tumour progression and metastasis. Nat Rev Cancer (2004) 4(1):71-8. doi: $10.1038 / \mathrm{nrc1} 256$

55. Biswas SK, Mantovani A. Macrophage plasticity and interaction with lymphocyte subsets: cancer as a paradigm. Nat Immunol (2010) 11(10):889-96. doi:10.1038/ni.1937

56. Gabrilovich DI, Nagaraj S. Myeloid-derived suppressor cells as regulators of the immune system. Nat Rev Immunol (2009) 9(3):162-74. doi:10.1038/nri2506

57. Movahedi K, Laoui D, Gysemans C, Baeten M, Stange G, Van den Bossche J, et al. Different tumor microenvironments contain functionally distinct subsets of macrophages derived from Ly6C(high) monocytes. Cancer Res (2010) 70(14):5728-39. doi:10. 1158/0008-5472.CAN-09-4672

58. Bonde AK, Tischler V, Kumar S, Soltermann A, Schwendener RA. Intratumoral macrophages contribute to epithelial-mesenchymal transition in solid tumors. BMC Cancer (2012) 12:35. doi:10.1186/ 1471-2407-12-35

59. Jinushi M, Baghdadi M, Chiba S, Yoshiyama H. Regulation of cancer stem cell activities by tumorassociated macrophages. Am J Cancer Res (2012) 2(5):529-39.

60. Eck M, Schmausser B, Scheller K, Brandlein S, Muller-Hermelink HK. Pleiotropic effects of CXC chemokines in gastric carcinoma: differences in CXCL8 and CXCL1 expression between diffuse and intestinal types of gastric carcinoma. Clin Exp Immunol (2003) 134(3):508$15 . \quad$ doi:10.1111/j.13652249.2003.02305.x
61. Jensen HK, Donskov F, Marcussen N, Nordsmark M, Lundbeck F, von der Maase H. Presence of intratumoral neutrophils is an independent prognostic factor in localized renal cell carcinoma. J Clin Oncol (2009) 27(28):4709-17. doi: 10.1200/JCO.2008.18.9498

62. Wislez M, Rabbe N, Marchal J, Milleron B, Crestani B, Mayaud C, et al. Hepatocyte growth factor production by neutrophils infiltrating bronchioloalveolar subtype pulmonary adenocarcinoma: role in tumor progression and death. Cancer Res (2003) 63(6):1405-12.

63. Bellocq A, Antoine M, Flahault A, Philippe C, Crestani B, Bernaudin JF, et al. Neutrophil alveolitis in bronchioloalveolar carcinoma: induction by tumorderived interleukin- 8 and relation to clinical outcome. Am J Pathol (1998) 152(1):83-92.

64. Schmielau J, Finn OJ. Activated granulocytes and granulocytederived hydrogen peroxide are the underlying mechanism of suppression of $\mathrm{t}$-cell function in advanced cancer patients. Cancer Res (2001) 61(12):4756-60.

65. Maeda H, Wu J, Sawa T, Matsumura Y, Hori K. Tumor vascular permeability and the EPR effect in macromolecular therapeutics: a review. J Control Release (2000) 65(1-2):271-84. doi:10. 1016/S0168-3659(99)00248-5

66. Iyer AK, Khaled G, Fang J, Maeda H. Exploiting the enhanced permeability and retention effect for tumor targeting. Drug Discov Today (2006) 11(17-18):812-8. doi:10.1016/j.drudis.2006.07.005

67. Jain RK. Delivery of molecular and cellular medicine to solid tumors. Adv Drug Deliv Rev (1997) 26(2-3):71-90. doi:10. 1016/S0169-409X(97)00027-6

68. Milosevic MF, Fyles AW, Wong R, Pintilie M, Kavanagh MC, Levin W, et al. Interstitial fluid pressure in cervical carcinoma: within tumor heterogeneity, and relation to oxygen tension. Cancer (1998) 82(12):241826 doi:10.1002/(SICI)10970142(19980615)82:12<2418:: AID-CNCR16>3.0.CO;2-S

69. Patan S, Munn LL, Jain RK. Intussusceptive microvascular growth in a human colon adenocarcinoma xenograft: a novel mechanism of tumor angiogenesis. Microvasc Res (1996) 51(2):260-72. doi:10.1006/ mvre.1996.0025

70. Padera TP, Stoll BR, Tooredman JB, Capen D, di Tomaso 
E, Jain RK. Pathology: cancer cells compress intratumour vessels. Nature (2004) 427(6976):695. doi:10.1038/427695a

71. Jain RK, Tong RT, Munn LL. Effect of vascular normalization by antiangiogenic therapy on interstitial hypertension, peritumor edema, and lymphatic metastasis: insights from a mathematical model. Cancer Res (2007) 67(6):2729-35. doi:10.1158/00085472.CAN-06-4102

72. Boucher Y, Baxter LT, Jain RK. Interstitial pressure gradients in tissue-isolated and subcutaneous tumors: implications for therapy. Cancer Res (1990) 50(15):4478-84.

73. Gatenby RA, Gillies RJ. Why do cancers have high aerobic glycolysis? Nat Rev Cancer (2004) 4(11):891-9. doi:10.1038/ \{lbreak\}nrc1478

74. Baxter LT, Jain RK. Transport of fluid and macromolecules in tumors. I. Role of interstitial pressure and convection. Microvasc Res (1989) 37(1):77-104. doi:10.1016/ 0026-2862(89)90074-5

75. Baxter LT, Jain RK. Transport of fluid and macromolecules in tumors. II. Role of heterogeneous perfusion and lymphatics. Microvasc Res (1990) 40(2):246-63. doi:10.1016/00262862(90)90023-K

76. Jain RK. Delivery of molecular medicine to solid tumors: lessons from in vivo imaging of gene expression and function. J Control Release (2001) 74(1-3):7-25. doi: 10.1016/S0168-3659(01)00306-6

77. Sevick EM, Jain RK. Effect of red blood cell rigidity on tumor blood flow: increase in viscous resistance during hyperglycemia. Cancer Res (1991) 51(10):2727-30.

78. Znati CA, Rosenstein M, Boucher Y, Epperly MW, Bloomer WD, Jain RK. Effect of radiation on interstitial fluid pressure and oxygenation in a human tumor xenograft. Cancer Res (1996) 56(5):964-8

79. Casazza A, Di Conza G, Wenes M, Finisguerra V, Deschoemaeker S, Mazzone M. Tumor stroma: a complexity dictated by the hypoxic tumor microenvironment. Oncogene (2013). doi: 10.1038/onc.2013.121. [Epub ahead of print].

80. Madara JL. Regulation of the movement of solutes across tight junctions. Annu Rev Physiol (1998) 60:143-59. doi:10.1146/annurev. physiol.60.1.143
81. Turksen K, Troy TC. Barriers built on claudins. J Cell Sci (2004) 117(Pt 12):2435-47. doi:10.1242/ jcs. 01235

82. Sasaki H. Freeze-fracture analysis of renal-epithelial tight junctions. Methods Mol Med (2003) 86:155-66.

83. Furuse M, Hirase T, Itoh M, Nagafuchi A, Yonemura S, Tsukita S. Occludin: a novel integral membrane protein localizing at tight junctions. J Cell Biol (1993) 123(6 Pt 2):1777-88. doi:10.1083/jcb. 123.6.1777

84. Liu Y, Nusrat A, Schnell FJ, Reaves TA, Walsh S, Pochet $M$, et al. Human junction adhesion molecule regulates tight junction resealing in epithelia. J Cell Sci (2000) 113(Pt 13):2363-74.

85. Cohen CJ, Shieh JT, Pickles RJ, Okegawa T, Hsieh JT, Bergelson JM. The coxsackievirus and adenovirus receptor is a transmembrane component of the tight junction. Proc Natl Acad Sci U S A (2001) 98(26):15191-6. doi:10. 1073/pnas.261452898

86. Ikenouchi J, Furuse M, Furuse K, Sasaki H, Tsukita S. Tricellulin constitutes a novel barrier at tricellular contacts of epithelial cells. J Cell Biol (2005) 171(6):939-45. doi:10.1083/jcb.200510043

87. Capaldo CT, Macara IG. Depletion of E-cadherin disrupts establishment but not maintenance of cell junctions in Madin-Darby canine kidney epithelial cells. Mol Biol Cell (2007) 18(1):189-200. doi:10. 1091/mbc.E06-05-0471

88. Bryant DM, Wylie FG, Stow JL. Regulation of endocytosis, nuclear translocation, and signaling of fibroblast growth factor receptor 1 by E-cadherin. Mol Biol Cell (2005) 16(1):14-23. doi:10.1091/ mbc.E04-09-0845

89. Qian X, Karpova T, Sheppard AM, McNally J, Lowy DR. E-cadherinmediated adhesion inhibits liganddependent activation of diverse receptor tyrosine kinases. $E M B O$ J (2004) 23(8):1739-48. doi:10. 1038/sj.emboj.7600136

90. Perrais M, Chen X, Perez-Moreno M, Gumbiner BM. E-cadherin homophilic ligation inhibits cell growth and epidermal growth factor receptor signaling independently of other cell interactions. Mol Biol Cell (2007) 18(6):201325. doi:10.1091/mbc.E06-04-0348

91. Moon RT, Bowerman B, Boutros M, Perrimon N. The promise and perils of Wnt signaling through beta-catenin. Science
(2002) 296(5573):1644-6. doi: 10.1126/science. 1071549

92. Soto E, Yanagisawa M, Marlow LA, Copland JA, Perez EA, Anastasiadis PZ. p120 Catenin induces opposing effects on tumor cell growth depending on E-cadherin expression. J Cell Biol (2008) 183(4):73749. doi:10.1083/jcb.200805113

93. Perez-Moreno M, Song W, Pasolli HA, Williams SE, Fuchs E. Loss of p120 catenin and links to mitotic alterations, inflammation, and skin cancer. Proc Natl Acad Sci U S A (2008) 105(40):15399-404. doi:10.1073/pnas.0807301105

94. Biedermann K, Vogelsang $H$, Becker I, Plaschke S, Siewert JR, Hofler $\mathrm{H}$, et al. Desmoglein 2 is expressed abnormally rather than mutated in familial and sporadic gastric cancer. $J$ Pathol (2005) 207(2):199-206. doi:10. 1002/path. 1821

95. Harada H, Iwatsuki K, Ohtsuka M, Han GW, Kaneko F. Abnormal desmoglein expression by squamous cell carcinoma cells. Acta Derm Venereol (1996) 76(6):417_ 20.

96. Chen J, Nekrasova OE, Patel DM, Klessner JL, Godsel LM, Koetsier JL, et al. The C-terminal unique region of desmoglein 2 inhibits its internalization via tailtail interactions. J Cell Biol (2012) 199(4):699-711. doi:10.1083/jcb. 201202105

97. Nava P, Laukoetter MG, Hopkins AM, Laur O, Gerner-Smidt $\mathrm{K}$, Green KJ, et al. Desmoglein-2: a novel regulator of apoptosis in the intestinal epithelium. Mol Biol Cell (2007) 18(11):4565-78. doi: 10.1091/mbc.E07-05-0426

98. Lipinski CA, Lombardo F, Dominy BW, Feeney PJ. Experimental and computational approaches to estimate solubility and permeability in drug discovery and development settings. Adv Drug Deliv Rev (2001) 46(1-3):3-26. doi:10.1016/ S0169-409X(00)00129-0

99. Lavin SR, McWhorter TJ, Karasov WH. Mechanistic bases for differences in passive absorption. J Exp Biol (2007) 210(Pt 15):2754-64. doi:10.1242/jeb.006114

100. Green SK, Karlsson MC, Ravetch JV, Kerbel RS. Disruption of cellcell adhesion enhances antibodydependent cellular cytotoxicity: implications for antibody-based therapeutics of cancer. Cancer Res (2002) 62(23):6891-900.

101. Fessler SP, Wotkowicz MT, Mahanta SK, Bamdad C. MUC1* is a determinant of trastuzumab
(Herceptin) resistance in breast cancer cells. Breast Cancer Res Treat (2009) 118(1):113-24. doi: 10.1007/s10549-009-0412-3

102. Oliveras-Ferraros C, VazquezMartin A, Cufi S, Queralt B, Baez L, Guardeno R, et al. Stem cell property epithelial-to-mesenchymal transition is a core transcriptional network for predicting cetuximab (Erbitux) efficacy in KRAS wild-type tumor cells. J Cell Biochem (2011) 112(1):10-29. doi:10.1002/jcb.22952

103. Lee CM, Tannock IF. The distribution of the therapeutic monoclonal antibodies cetuximab and trastuzumab within solid tumors. BMC Cancer (2010) 10:255. doi: 10.1186/1471-2407-10-255

104. Christiansen JJ, Rajasekaran AK. Reassessing epithelial to mesenchymal transition as a prerequisite for carcinoma invasion and metastasis. Cancer Res (2006) 66(17):8319-26. doi:10. 1158/0008-5472.CAN-06-0410

105. Shelly M, Mosesson Y, Citri A, Lavi S, Zwang Y, Melamed-Book N, et al. Polar expression of ErbB2/HER2 in epithelia. Bimodal regulation by Lin-7. Dev Cell (2003) 5(3):475-86. doi:10.1016/j.devcel. 2003.08.001

106. Toledo C, Matus CE, Barraza X, Arroyo P, Ehrenfeld P, Figueroa $\mathrm{CD}$, et al. Expression of HER2 and bradykinin $\mathrm{B}(1)$ receptors in precursor lesions of gallbladder carcinoma. World J Gastroenterol (2012) 18(11):1208-15. doi: 10.3748/wjg.v18.i11.1208

107. Tong WM, Ellinger A, Sheinin Y, Cross HS. Epidermal growth factor receptor expression in primary cultured human colorectal carcinoma cells. $\mathrm{Br} J$ Cancer (1998) 77(11):1792-8. doi:10. 1038/bjc. 1998.298

108. Vermeer PD, Einwalter LA, Moninger TO, Rokhlina T, Kern JA, Zabner J, et al. Segregation of receptor and ligand regulates activation of epithelial growth factor receptor. Nature (2003) 422(6929):322-6. doi: 10.1038 /nature01440

109. Beyer I, van Rensburg R, Strauss $\mathrm{R}$, Li Z, Wang $\mathrm{H}$, Persson J, et al. Epithelial junction opener JO-1 improves monoclonal antibody therapy of cancer. Cancer Res (2011) 71(22):7080-90. doi:10. 1158/0008-5472.CAN-11-2009

110. Thiery JP, Acloque H, Huang RY, Nieto MA. Epithelialmesenchymal transitions in development and disease. Cell 
(2009) 139(5):871-90. doi: 10.1016/j.cell.2009.11.007

111. Wong AS, Auersperg N. Normal ovarian surface epithelium. Cancer Treat Res (2002) 107:161-83.

112. Brabletz T, Jung A, Spaderna S, Hlubek F, Kirchner T. Opinion: migrating cancer stem cells an integrated concept of malignant tumour progression. Nat Rev Cancer (2005) 5(9):744-9. doi:10. 1038/nrc1694

113. Come C, Magnino F, Bibeau F, De Santa Barbara P, Becker KF, Theillet $C$, et al. Snail and slug play distinct roles during breast carcinoma progression. Clin Cancer Res (2006) 12(18):5395-402. doi: 10.1158/1078-0432.CCR-06-0478

114. Arnoux V, Come C, Kusewitt D, Hudson L, Savagner P. Cutaneous wound reepithelization: a partial and reversible EMT. In: Savagner P, editor. Rise and Fall of Epithelial Phenotype: Concepts of EpithelialMesenchymal Transition. Berlin: Springer (2005). p. 111-34.

115. Kalluri R, Weinberg RA. The basics of epithelial-mesenchymal transition. $J$ Clin Invest (2009) 119(6):1420-8. doi: 10.1172/JCI39104

116. Birchmeier W, Behrens J. Cadherin expression in carcinomas: role in the formation of cell junctions and the prevention of invasiveness. Biochim Biophys Acta (1994) 1198(1):11-26.

117. Sabbah M, Emami S, Redeuilh G, Julien S, Prevost G, Zimber A, et al. Molecular signature and therapeutic perspective of the epithelialto-mesenchymal transitions in epithelial cancers. Drug Resist Updat (2008) 11(4-5):123-51. doi: 10.1016/j.drup.2008.07.001

118. Nieto MA. The snail superfamily of zinc-finger transcription factors. Nat Rev Mol Cell Biol (2002) 3(3):155-66. doi:10.1038/nrm757

119. Leptin M. Twist and snail as positive and negative regulators during Drosophila mesoderm development. Genes Dev (1991) 5(9):1568-76. doi:10.1101/gad.5. 9.1568

120. Batlle E, Sancho E, Franci C, Dominguez D, Monfar M, Baulida J, et al. The transcription factor snail is a repressor of E-cadherin gene expression in epithelial tumour cells. Nat Cell Biol (2000) 2(2):84-9. doi:10. 1038/35000034

121. Postigo AA, Depp JL, Taylor JJ, Kroll KL. Regulation of Smad signaling through a differential recruitment of coactivators and corepressors by ZEB proteins. EMBO J (2003) 22(10):2453-62. doi:10.1093/emboj/cdg226

122. Ellenberger T, Fass D, Arnaud M, Harrison SC. Crystal structure of transcription factor E47: E-box recognition by a basic region helix-loop-helix dimer. Genes Dev (1994) 8(8):970-80. doi:10.1101/ gad.8.8.970

123. Ikenouchi J, Matsuda M, Furuse M, Tsukita S. Regulation of tight junctions during the epithelium-mesenchyme transition: direct repression of the gene expression of claudins/occludin by Snail. J Cell Sci (2003) 116(Pt 10):1959-67. doi:10.1242/jcs.00389

124. Ohkubo T, Ozawa M. The transcription factor Snail downregulates the tight junction components independently of E-cadherin downregulation. J Cell Sci (2004) 117(Pt 9):1675-85. doi:10.1242/ jcs. 01004

125. Vandewalle C, Comijn J, De Craene B, Vermassen P, Bruyneel E, Andersen $\mathrm{H}$, et al. SIP1/ZEB2 induces EMT by repressing genes of different epithelial cell-cell junctions. Nucleic Acids Res (2005) 33(20):6566-78. doi:10.1093/nar/ gki965

126. Martinez-Estrada OM, Culleres A, Soriano FX, Peinado H, Bolos V, Martinez FO, et al. The transcription factors Slug and Snail act as repressors of claudin-1 expression in epithelial cells. Biochem $J$ (2006) 394(Pt 2):449-57. doi:10. 1042/BJ20050591

127. Yang J, Mani SA, Donaher JL, Ramaswamy S, Itzykson RA, Come $\mathrm{C}$, et al. Twist, a master regulator of morphogenesis, plays an essential role in tumor metastasis. Cell (2004) 117(7):927-39. doi: 10.1016/j.cell.2004.06.006

128. Perez-Moreno MA, Locascio A, Rodrigo I, Dhondt G, Portillo F, Nieto MA, et al. A new role for E12/E47 in the repression of E-cadherin expression and epithelialmesenchymal transitions. J Biol Chem (2001) 276(29):27424-31. doi:10.1074/jbc.M100827200

129. Thiery JP. Epithelial-mesenchymal transitions in tumour progression. Nat Rev Cancer (2002) 2(6):44254. doi: $10.1038 / \mathrm{nrc} 822$

130. Panorchan P, Thompson MS, Davis KJ, Tseng Y, Konstantopoulos K, Wirtz D. Single-molecule analysis of cadherin-mediated cellcell adhesion. J Cell Sci (2006)
119(Pt 1):66-74. doi:10.1242/jcs. 02719

131. Janmey PA, Euteneuer U, Traub P, Schliwa M. Viscoelastic properties of vimentin compared with other filamentous biopolymer networks. J Cell Biol (1991) 113(1):155-60. doi: 10.1083/jcb.113.1.155

132. Wagner OI, Rammensee S, Korde $\mathrm{N}$, Wen $\mathrm{Q}$, Leterrier JF, Janmey PA. Softness, strength and self-repair in intermediate filament networks. Exp Cell Res (2007) 313(10):2228-35. doi:10. 1016/j.yexcr.2007.04.025

133. LaGamba D, Nawshad A, Hay ED. Microarray analysis of gene expression during epithelialmesenchymal transformation. Dev Dyn (2005) 234(1):132-42. doi:10.1002/dvdy.20489

134. Brabletz T, Jung A, Reu S, Porzner M, Hlubek F, Kunz-Schughart LA, et al. Variable beta-catenin expression in colorectal cancers indicates tumor progression driven by the tumor environment. Proc Natl Acad Sci U S A (2001) 98(18):10356-61. doi:10. 1073/pnas.171610498

135. Strauss R, Li ZY, Liu Y, Beyer I, Persson J, Sova P, et al. Analysis of epithelial and mesenchymal markers in ovarian cancer reveals phenotypic heterogeneity and plasticity. PLoS ONE (2011) 6(1):e16186. doi:10.1371/journal. pone. 0016186

136. Visvader JE, Lindeman GJ. Cancer stem cells in solid tumours: accumulating evidence and unresolved questions. Nat Rev Cancer (2008) 8(10):755-68. doi:10.1038/ nrc2499

137. Marhaba R, Klingbeil P, Nuebel T, Nazarenko I, Buechler MW, Zoeller M. CD44 and EpCAM: cancerinitiating cell markers. Curr $\mathrm{Mol}$ Med (2008) 8(8):784-804. doi:10. 2174/156652408786733667

138. Yu M, Bardia A, Wittner BS, Stott SL, Smas ME, Ting DT, et al. Circulating breast tumor cells exhibit dynamic changes in epithelial and mesenchymal composition. Science (2013) 339(6119):580-4. doi: $10.1126 /$ science. 1228522

139. Tsai JH, Donaher JL, Murphy DA, Chau S, Yang J. Spatiotemporal regulation of epithelialmesenchymal transition is essential for squamous cell carcinoma metastasis. Cancer Cell (2012) 22(6):725-36. doi:10.1016/ j.ccr.2012.09.022

140. Ocana OH, Corcoles R, Fabra A, Moreno-Bueno G, Acloque H,
Vega S, et al. Metastatic colonization requires the repression of the epithelial-mesenchymal transition inducer Prrxl. Cancer Cell (2012) 22(6):709-24. doi:10.1016/ j.ccr.2012.10.012

141. Saito $T$, Nagai $M$, Ladanyi $M$. SYT-SSX1 and SYT-SSX2 interfere with repression of E-cadherin by snail and slug: a potential mechanism for aberrant mesenchymal to epithelial transition in human synovial sarcoma. Cancer Res (2006) 66(14):691927. doi:10.1158/0008-5472.CAN05-3697

142. Fitzgerald MP, Gourronc F, Teoh ML, Provenzano MJ, Case AJ, Martin JA, et al. Human chondrosarcoma cells acquire an epitheliallike gene expression pattern via an epigenetic switch: evidence for mesenchymal-epithelial transition during sarcomagenesis. Sarcoma (2011) 2011:598218. doi:10.1155/ 2011/598218

143. Egeblad M, Rasch MG, Weaver VM. Dynamic interplay between the collagen scaffold and tumor evolution. Curr Opin Cell Biol (2010) 22(5):697-706. doi: 10.1016/j.ceb.2010.08.015

144. Bjorge L, Junnikkala S, Kristoffersen EK, Hakulinen J, Matre $\mathrm{R}$, Meri S. Resistance of ovarian teratocarcinoma cell spheroids to complement-mediated lysis. $\mathrm{Br} \mathrm{J}$ Cancer (1997) 75(9):1247-55. doi: 10.1038/bjc.1997.213

145. Brown E, McKee T, diTomaso E Pluen A, Seed B, Boucher Y, et al. Dynamic imaging of collagen and its modulation in tumors in vivo using second-harmonic generation. Nat Med (2003) 9(6):796800. doi:10.1038/nm879

146. Eikenes L, Tufto I, Schnell EA, Bjorkoy A, De Lange Davies C. Effect of collagenase and hyaluronidase on free and anomalous diffusion in multicellular spheroids and xenografts. Anticancer Res (2010) 30(2):359-68.

147. Kuriyama N, Kuriyama H, Julin CM, Lamborn K, Israel MA. Pretreatment with protease is a useful experimental strategy for enhancing adenovirus-mediated cancer gene therapy. Hum Gene Ther (2000) 11(16):2219-30. doi:10. 1089/104303400750035744

148. McKee TD, Grandi P, Mok W, Alexandrakis G, Insin N, Zimmer JP, et al. Degradation of fibrillar collagen in a human melanoma xenograft improves the efficacy of an oncolytic herpes simplex virus vector. Cancer Res (2006) 
66(5):2509-13. doi:10.1158/00085472.CAN-05-2242

149. Ganesh S, Gonzalez-Edick M, Gibbons D, Van Roey M, Jooss K. Intratumoral coadministration of hyaluronidase enzyme and oncolytic adenoviruses enhances virus potency in metastatic tumor models. Clin Cancer Res (2008) 14(12):3933-41. doi: 10.1158/1078-0432.CCR-07-4732

150. Cheng J, Sauthoff H, Huang Y, Kutler DI, Bajwa S, Rom WN, et al. Human matrix metalloproteinase8 gene delivery increases the oncolytic activity of a replicating adenovirus. Mol Ther (2007) 15(11):1982-90. doi: 10.1038/sj.mt.6300264

151. Mok W, Boucher Y, Jain RK. Matrix metalloproteinases-1 and -8 improve the distribution and efficacy of an oncolytic virus. Cancer Res (2007) 67(22):10664-8. doi:10.1158/0008-5472.CAN-073107

152. Coussens LM, Werb Z. Matrix metalloproteinases and the development of cancer. Chem Biol (1996) 3(11):895-904. doi: 10.1016/S1074-5521(96)90178-7

153. Kessenbrock K, Plaks V, Werb Z. Matrix metalloproteinases: regulators of the tumor microenvironment. Cell (2010) 141(1):52-67. doi:10.1016/j.cell.2010.03.015

154. Ganesh S, Gonzalez Edick M, Idamakanti $\mathrm{N}$, Abramova $\mathrm{M}$, Vanroey $M$, Robinson $M$, et al. Relaxin-expressing, fiber chimeric oncolytic adenovirus prolongs survival of tumorbearing mice. Cancer Res (2007) 67(9):4399-407. doi: 10.1158/0008-5472.CAN-064260

155. Kim JH, Lee YS, Kim H, Huang $\mathrm{JH}$, Yoon AR, Yun CO. Relaxin expression from tumor-targeting adenoviruses and its intratumoral spread, apoptosis induction, and efficacy. J Natl Cancer Inst (2006) 98(20):1482-93. doi:10.1093/jnci/ djj397

156. Beyer I, Li Z, Persson J, Liu Y, van Rensburg R, Yumul R, et al. Controlled extracellular matrix degradation in breast cancer tumors improves therapy by trastuzumab. Mol Ther (2011) 19(3):479-89. doi:10.1038/mt.2010.256

157. Li Z, Liu Y, Tuve S, Xun Y, Fan X, Min L, et al. Toward a stem cell gene therapy for breast cancer. Blood (2009) 113(22):5423-33. doi:10. 1182/blood-2008-10-187237

158. Choi IK, Lee YS, Yoo JY, Yoon AR, Kim H, Kim DS, et al.
Effect of decorin on overcoming the extracellular matrix barrier for oncolytic virotherapy. Gene Ther (2010) 17(2):190-201. doi: 10.1038/gt.2009.142

159. Dschietzig T, Bartsch C, Baumann G, Stangl K. Relaxin-a pleiotropic hormone and its emerging role for experimental and clinical therapeutics. Pharmacol Ther (2006) 112(1):38-56. doi:10.1016/ j.pharmthera.2006.03.004

160. Sherwood OD. Relaxin's physiological roles and other diverse actions. Endocr Rev (2004) 25(2):205-34. doi: 10.1210/er.2003-0013

161. Van Der Westhuizen ET, Summers RJ, Halls ML, Bathgate RA, Sexton PM. Relaxin receptors new drug targets for multiple disease states. Curr Drug Targets (2007) 8(1):91-104. doi:10.2174/ 138945007779315650

162. Amento EP, Bhan AK, McCullagh KG, Krane SM. Influences of gamma interferon on synovial fibroblast-like cells. Ia induction and inhibition of collagen synthesis. J Clin Invest (1985) 76(2):83748. doi:10.1172/JCI112041

163. Bathgate RA, Lekgabe ED, McGuane JT, Su Y, Pham T, Ferraro T, et al. Adenovirusmediated delivery of relaxin reverses cardiac fibrosis. Mol Cell Endocrinol (2008) 280(1-2):30-8. doi:10.1016/j.mce.2007.09.008

164. Cernaro V, Lacquaniti A, Lupica R, Buemi A, Trimboli D, Giorgianni G, et al. Relaxin: new pathophysiological aspects and pharmacological perspectives for an old protein. Med Res Rev (2013). doi:10.1002/ med.21277. [Epub ahead of print].

165. Silvertown JD, Ng J, Sato T, Summerlee AJ, Medin JA. H2 relaxin overexpression increases in vivo prostate xenograft tumor growth and angiogenesis. Int $J$ Cancer (2006) 118(1):62-73. doi:10.1002/ ijc. 21288

166. Silvecrtown JD, Symes JC, Neschadim A, Nonaka T, Kao JC, Summerlee AJ, et al. Analog of $\mathrm{H} 2$ relaxin exhibits antagonistic properties and impairs prostate tumor growth. FASEB $J$ (2007) 21(3):754-65. doi: 10.1096/fj.06-6847com

167. Binder C, Hagemann T, Husen B, Schulz M, Einspanier A. Relaxin enhances in-vitro invasiveness of breast cancer cell lines by upregulation of matrix metalloproteases. Mol Hum Reprod (2002) 8(9):789-96. doi:10.1093/molehr/ 8.9 .789
168. Radestock Y, Hoang-Vu C, Hombach-Klonisch S. Relaxin reduces xenograft tumour growth of human MDA-MB-231 breast cancer cells. Breast Cancer Res (2008) 10(4):R71. doi: $10.1186 / \mathrm{bcr} 2136$

169. Vogel KG, Paulsson M, Heinegard D. Specific inhibition of type I and type II collagen fibrillogenesis by the small proteoglycan of tendon. Biochem J (1984) 223(3):587-97.

170. Yamaguchi Y, Mann DM, Ruoslahti E. Negative regulation of transforming growth factor-beta by the proteoglycan decorin. Nature (1990) 346(6281):281-4. doi:10. 1038/346281a0

171. Danielson KG, Baribault H, Holmes DF, Graham H, Kadler KE, Iozzo RV. Targeted disruption of decorin leads to abnormal collagen fibril morphology and skin fragility. J Cell Biol (1997) 136(3):729-43. doi: 10.1083/jcb.136.3.729

172. Wei H, Liu P, Swisher E, Yip YY, Tse JH, Agnew $K$, et al. Silencing of the TGF-betal gene increases the immunogenicity of cells from human ovarian carcinoma. J Immunother (2012) 35(3):267-75. doi 10.1097/CJI.0b013e31824d72ee

173. Sonoda N, Furuse M, Sasaki H, Yonemura S, Katahira J, Horiguchi $\mathrm{Y}$, et al. Clostridium perfringens enterotoxin fragment removes specific claudins from tight junction strands: evidence for direct involvement of claudins in tight junction barrier. J Cell Biol (1999) 147(1):195-204. doi:10.1083/jcb. 147.1.195

174. Fasano A, Baudry B, Pumplin DW, Wasserman SS, Tall BD, Ketley $\mathrm{JM}$, et al. Vibrio cholerae produces a second enterotoxin, which affects intestinal tight junctions. Proc Natl Acad Sci U S A (1991) 88(12):5242-6. doi:10.1073/pnas. 88.12.5242

175. Cox DS, Raje S, Gao H, Salama NN, Eddington ND. Enhanced permeability of molecular weight markers and poorly bioavailable compounds across Caco-2 cell monolayers using the absorption enhancer, zonula occludens toxin Pharm Res (2002) 19(11):1680-8. doi:10.1023/A:1020709513562

176. Latorre IJ, Roh MH, Frese KK, Weiss RS, Margolis B, Javier RT. Viral oncoprotein-induced mislocalization of select PDZ proteins disrupts tight junctions and causes polarity defects in epithelial cells. J Cell Sci (2005)
118(Pt 18):4283-93. doi:10.1242/ jcs. 02560

177. Walters RW, Freimuth P, Moninger TO, Ganske I, Zabner J, Welsh MJ. Adenovirus fiber disrupts CAR-mediated intercellular adhesion allowing virus escape. Cell (2002) 110(6):789-99. doi: 10.1016/S0092-8674(02)00912-1

178. Coyne CB, Shen L, Turner JR, Bergelson JM. Coxsackievirus entry across epithelial tight junctions requires occludin and the small GTPases Rab34 and Rab5. Cell Host Microbe (2007) 2(3):181-92. doi: 10.1016/j.chom.2007.07.003

179. Muhlebach MD, Mateo M, Sinn PL, Prufer S, Uhlig KM, Leonard $\mathrm{VH}$, et al. Adherens junction protein nectin-4 is the epithelial receptor for measles virus. Nature (2011) 480(7378):530-3. doi:10. 1038/nature10639

180. Aungst BJ. Intestinal permeation enhancers. $J$ Pharm Sci (2000) 89(4):429-42. doi:10.1002/(SICI)15206017(200004)89:4<429::AIDJPS1>3.0.CO;2-J

181. Wang H, Li ZY, Liu Y, Persson J, Beyer I, Moller T, et al. Desmoglein 2 is a receptor for adenovirus serotypes 3, 7, 11 and 14. Nat Med (2011) 17(1):96-104. doi:10.1038/ nm. 2270

182. Wang H, Li Z, Yumul R, Lara $\mathrm{S}$, Hemminki A, Fender P, et al. Multimerization of adenovirus serotype 3 fiber knob domains is required for efficient binding of virus to desmoglein 2 and subsequent opening of epithelial junctions. J Virol (2011) 85(13):6390402. doi:10.1128/JVI.00514-11

183. Beyer I, Cao H, Persson J, Song H, Richter M, Feng Q, et al. Coadministration of epithelial junction opener JO-1 improves the efficacy and safety of chemotherapeutic drugs. Clin Cancer Res (2012) 18(12):3340-51. doi:10. 1158/1078-0432.CCR-11-3213

184. Su YC, Chen BM, Chuang KH, Cheng TL, Roffler SR. Sensitive quantification of PEGylated compounds by secondgeneration anti-poly(ethylene glycol) monoclonal antibodies. Bioconjug Chem (2010) 21(7):126470. doi:10.1021/bc100067t

185. Wang H, Beyer I, Persson J, Song H, Li Z, Richter M, et al. A new human DSG2-transgenic mouse model for studying the tropism and pathology of human adenoviruses. JVirol (2012) 86(11):6286-302. doi:10. 1128/JVI.00205- 12 
186. Guarino M. Epithelialmesenchymal transition and tumour invasion. Int $J$ Biochem Cell Biol (2007) 39(12):2153-60. doi:10.1016/j.biocel.2007.07.011

187. Dhar D, Spencer JF, Toth K, Wold WS. Pre-existing immunity and passive immunity to adenovirus 5 prevents toxicity caused by an oncolytic adenovirus vector in the Syrian hamster model. Mol Ther (2009) 17(10):1724-32. doi: 10.1038/mt.2009.156

188. Thomas MA, Spencer JF, Toth K, Sagartz JE, Phillips NJ, Wold WS. Immunosuppression enhances oncolytic adenovirus replication and antitumor efficacy in the Syrian hamster model. Mol Ther (2008) 16(10):1665-73. doi: 10.1038/mt.2008.162

189. Bouvet M, Fang B, Ekmekcioglu S, Ji L, Bucana CD, Hamada K, et al. Suppression of the immune response to an adenovirus vector and enhancement of intratumoral transgene expression by low-dose etoposide. Gene Ther (1998) 5(2):189-95. doi:10.1038/ sj.gt.3300564

190. Sinha P, Clements VK, Ostrand-Rosenberg S. Interleukin13-regulated M2 macrophages in combination with myeloid suppressor cells block immune surveillance against metastasis. Cancer Res (2005) 65(24):1174351. doi:10.1158/0008-5472.CAN05-0045

191. Zou W. Regulatory T cells, tumour immunity and immunotherapy. Nat Rev Immunol (2006) 6(4):295307. doi: $10.1038 /$ nri1806

192. Kimura YN, Watari K, Fotovati A, Hosoi F, Yasumoto K, Izumi $\mathrm{H}$, et al. Inflammatory stimuli from macrophages and cancer cells synergistically promote tumor growth and angiogenesis. Cancer Sci (2007) 98(12):2009-18. doi:10. 1111/j.1349-7006.2007.00633.x

193. Luo Y, Zhou H, Krueger J, Kaplan C, Lee SH, Dolman C, et al. Targeting tumor-associated macrophages as a novel strategy against breast cancer. $J$ Clin Invest (2006) 116(8):2132-41. doi: 10.1172/JCI27648

194. Fujimoto H, Sangai T, Ishii G, Ikehara A, Nagashima T, Miyazaki M, et al. Stromal MCP-1 in mammary tumors induces tumor-associated macrophage infiltration and contributes to tumor progression. Int $J$ Cancer (2009) 125(6):1276-84. doi:10.1002/ijc. 24378

195. Zeisberger SM, Odermatt B, Marty C, Zehnder-Fjallman AH, BallmerHofer K, Schwendener RA. Clodronate-liposome-mediated depletion of tumour-associated macrophages: a new and highly effective antiangiogenic therapy approach. $\mathrm{Br} \quad J$ Cancer (2006) 95(3):272-81. doi: 10.1038/sj.bjc.6603240

196. Mitchem JB, Brennan DJ, Knolhoff BL, Belt BA, Zhu Y, Sanford DE, et al. Targeting tumor-infiltrating macrophages decreases tumor-initiating cells, relieves immunosuppression, and improves chemotherapeutic responses. Cancer Res (2013) 73(3):1128-41. doi:10.1158/00085472.CAN-12-2731

197. Aboody KS, Najbauer J, Metz MZ, D’Apuzzo M, Gutova M, Annala AJ, et al. Neural stem cell-mediated enzyme/prodrug therapy for glioma: preclinical studies. Sci Transl Med (2013) 5(184):184ra59. doi: 10.1126/scitranslmed.3005365

198. Arora A, Scholar EM. Role of tyrosine kinase inhibitors in cancer therapy. J Pharmacol Exp Ther (2005) 315(3):971-9. doi:10.1124/ jpet.105.084145

199. Mok TS, Wu YL, Thongprasert S, Yang $\mathrm{CH}$, Chu DT, Saijo N, et al. Gefitinib or carboplatin-paclitaxel in pulmonary adenocarcinoma. $N$ Engl J Med (2009) 361(10):947-57. doi:10.1056/NEJMoa0810699

200. Chua KN, Sim WJ, Racine V, Lee SY, Goh BC, Thiery JP. A cellbased small molecule screening method for identifying inhibitors of epithelial-mesenchymal transition in carcinoma. PLoS ONE (2012) 7(3):e33183. doi:10.1371/ journal.pone. 0033183

201. Reka AK, Kurapati H, Narala VR, Bommer G, Chen J, Standiford TJ, et al. Peroxisome proliferatoractivated receptor-gamma activation inhibits tumor metastasis by antagonizing Smad3mediated epithelial-mesenchymal transition. Mol Cancer Ther (2010) 9(12):3221-32. doi:10.1158/15357163.MCT-10-0570

202. Yang J, Shultz RW, Mars WM, Wegner RE, Li Y, Dai C, et al. Disruption of tissue-type plasminogen activator gene in mice reduces renal interstitial fibrosis in obstructive nephropathy. J Clin Invest (2002) 110(10): 1525-38. doi:10.1172 JCI200216219

203. Kobayashi A, Okuda H, Xing F, Pandey PR, Watabe M, Hirota S, et al. Bone morphogenetic protein 7 in dormancy and metastasis of prostate cancer stemlike cells in bone. J Exp Med (2011) 208(13):2641-55. doi:10 1084/jem.20110840

204. Qi L, Sun B, Liu Z, Li H, Gao J, Leng X. Dickkopf-1 inhibits epithelial-mesenchymal transition of colon cancer cells and contributes to colon cancer suppression. Cancer Sci (2012) 103(4):828 35 doi:10.1111/j.13497006.2012.02222.x

205. Scheel C, Eaton EN, Li SH, Chaffer CL, Reinhardt F, Kah KJ, et al. Paracrine and autocrine signals induce and maintain mesenchymal and stem cell states in the breast. Cell (2011) 145(6):926-40. doi:10.1016/j.cell.2011.04.029

206. Strauss R, Sova P, Liu Y, Li Z-Y, Tuve S, Pritchard D, et al. Epithelial phenotype of ovarian cancer mediates resistance to oncolytic adenoviruses. Cancer Res (2009) 15(69):5115-25. doi:10. 1158/0008-5472.CAN-09-0645

Conflict of Interest Statement: The authors declare that the research was conducted in the absence of any commercial or financial relationships that could be construed as a potential conflict of interest.

Received: 30 May 2013; paper pending published: 13 June 2013; accepted: 11 July 2013; published online: 26 July 2013.

Citation: Choi I-K, Strauss R, Richter M, Yun C-O and Lieber A (2013) Strategies to increase drug penetration in solid tumors. Front. Oncol. 3:193. doi: 10.3389/fonc. 2013.00193

This article was submitted to Frontiers in Pharmacology of Anti-Cancer Drugs, a specialty of Frontiers in Oncology. Copyright $\odot 2013$ Choi, Strauss, Richter, Yun and Lieber. This is an open-access article distributed under the terms of the Creative Commons Attribution License, which permits use, distribution and reproduction in other forums, provided the original authors and source are credited and subject to any copyright notices concerning any third-party graphics etc. 